"This is the peer reviewed version of the following article: Synthesis, Application and Kinetic Studies of Chiral PhosphiteOxazoline Palladium Complexes as Active and Selective Catalysts in Intermolecular Heck Reactions, which has been published in final form at https://doi.org/10.1002/adsc.201701603. This article may be used for non-commercial purposes in accordance with Wiley Terms and Conditions for Self-Archiving http://olabout.wiley.com/WileyCDA/Section/id820227.html".

\title{
Synthesis, Application and Kinetic Studies of Chiral Phosphite- Oxazoline Palladium Complexes as Active and Selective Catalysts in Intermolecular Heck Reactions
}

\author{
Zahra Mazloomi, ${ }^{a}$ Marc Magre, ${ }^{a}$ Efrem Del Valle, ${ }^{a}$ Miquel A. Pericàs, ${ }^{b, c}$ Oscar \\ Pàmies, ${ }^{a *}$ P. W. N. M. van Leeuwen ${ }^{\mathrm{d} *}$ and Montserrat Diéguez ${ }^{\mathrm{a} *}$
}

a Universitat Rovira i Virgili, Departament de Química Física i Inorgànica, C/ Marcel·lí Domingo, 1, 43007 Tarragona, Spain. Fax: (+34)977559563; Tel: (+34)977558780; email: oscar.pamies@urv.cat; montserrat.dieguez@urv.cat.

b Institute of Chemical Research of Catalonia (ICIQ), The Barcelona Institute of Science and Technology, Av. Països Catalans 16, 43007 Tarragona, Spain.

c Departament de Química Inorgànica i Orgànica. Universitat de Barcelona. 08028 Barcelona, Spain.

d LPCNO, Laboratoire de Physique et Chimie des Nano-Objets, INSA-Toulouse, 135, Avenue de Rangueil, F-31077

Toulouse, France; Tel: (+33)0567048857; email: vanleeuw@insa-toulouse.fr.

\begin{abstract}
This study identifies new phosphite-oxazoline ligands that have been successfully applied in the palladiumcatalyzed intermolecular asymmetric Heck reaction. The design of the new phosphite-oxazoline ligands derives from a previous successful generation of phosphine-oxazoline ligands, by replacing the phosphine group with several $\pi$ acceptor biaryl phosphite moieties. With these simple modifications, the new phosphite-based ligands, unlike previous phosphine-oxazoline, not only present a modular design with numerous potential phosphite groups available, but they are also air-stable solids, which can be made in the same number of synthetic steps as the phosphine analogues. The substitution of the phosphine by a biaryl phosphite group extended the range of substrates and triflates sources that can
\end{abstract}

be coupled with regio-, enantioselectivities and activities comparable to the few best ones reported. In addition, the ligands that provided the best selectivities contained an isopropyl oxazoline moiety instead of the tert-butyl group found in the related phosphine-oxazoline ligands, which is made from a much more expensive precursor. In this paper we have also carried out kinetic studies and a Hammett plot analysis to determine the rate determining step of this system in the regime of interest. We suggest a likely explanation for the fast Heck reaction of the phosphite-oxazoline catalysts.

Keywords: Palladium; Intermolecular Heck reaction; P,Nligands; asymmetric catalysis; kinetic study

\section{Introduction}

The Pd-catalyzed Heck reaction (also known as Mizoroki-Heck reaction), i.e., the coupling of an alkenyl or aryl (pseudo)halide to an alkene, is one of the most powerful $\mathrm{C}-\mathrm{C}$ bond forming reactions, and Heck's contribution was recognized with the Nobel Prize in Chemistry in 2010, shared with Negishi and Suzuki. ${ }^{[1]}$ Its applicability to highly functionalized substrates confers the reaction a large substrate scope and it is widely applied in the synthesis of pharmaceuticals, natural products, and fine chemicals. ${ }^{[1]}$ The extensive research dedicated to this process can give the erroneous impression that Heck chemistry is a mature area. Although the Heck reaction has been known since the late 1960s, its asymmetric version was not published until 1980, with most examples dealing with intramolecular reactions, in which the alkene regiochemistry and geometry of the product can be easily controlled. ${ }^{[1]}$ The asymmetric intermolecular Heck reaction was not published until
1991. ${ }^{[2]}$ Although since then many research groups have devoted considerable efforts to the intermolecular version, it is still less developed than the intramolecular version and its synthetic utility remains limited. This is due in part to regioselectivity issues caused by the possible displacement of the carbon-carbon double bond, which leads to mixtures of products. For example, in the Heck coupling of the model substrate 2,3-dihydrofuran (S1) with phenyl triflate (Scheme 1), both the 2-phenyl-2,5dihydrofuran (1) and the 2-phenyl-2,3-dihydrofuran (2) can be obtained.

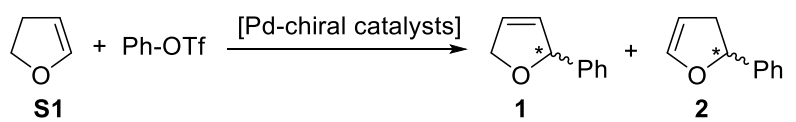

Scheme 1. Model Pd-catalyzed Heck reaction of 2,3dihydrofuran (S1) with phenyl triflate 
In the beginning, the research in the asymmetric intermolecular reaction focused on the development of diphosphine ligands, BINAP being the central ligand ${ }^{[1]}$ Although Pd-diphosphine catalysts provided high enantioselectivities, the regioselectivity and activity were less favorable (e.g., BINAP provided enantioselectivities up to $96 \%$ but the main product was 2 , in only $71 \%$ of regioselectivity, and the reaction time was 9 days ${ }^{[2]}$. This moved the research to other types of ligands. A breakthrough was the report by Pfaltz et al., who showed that phosphine-oxazoline PHOX ligands (3, Figure 1) minimized the double bond isomerization providing high regio- and enantioselectivity to product $\mathbf{1}$, although still at low activity with long reaction times (3-7 days to achieve full conversion). ${ }^{[3]}$ Then, the follow up work for the intermolecular Heck reaction focused on Pd-catalysts with modified chiral phosphine-oxazoline ligands. ${ }^{[4,5]}$ Of the many ligands developed, only a few provided high selectivity (Figure 1) and reaction rates and substrate specificity could not be improved significantly either. Although microwave irradiation considerably reduced the reaction times from weeks to days, it affected enantioselectivity - and sometimes regioselectivity - negatively. ${ }^{[6]}$ Additionally, the most successful phosphine-oxazoline ligands contained a ${ }^{\mathrm{t}} \mathrm{Bu}$ group in the oxazoline and their synthesis required the use of the expensive amino acid tert-leucine. Although alternative phosphine-oxazoline ligands, such as those incorporating geminal substituents at C4 of $\operatorname{Pr}-\mathrm{PHOX},{ }^{[4 \mathrm{q}]}$ were developed to solve this limitation, they had smaller substrate scope and/or their synthesis required more reaction steps. A final limitation of phosphine-oxazoline ligands is that most of them are prone to oxidation. Thus, while the PHOX ligands were found to be extremely successful in many reactions ${ }^{[7]}$ there remains room for improvement in the intermolecular Heck reactions.
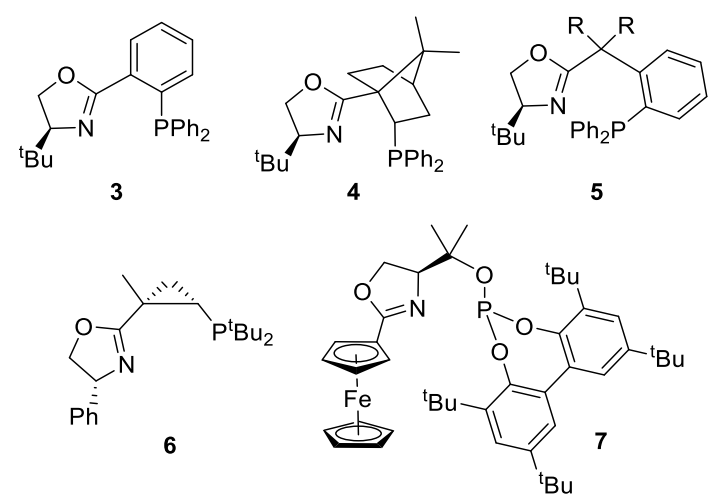

Figure 1. Representative privileged P-oxazoline ligands for Pd-catalyzed asymmetric intermolecular Heck reactions.

The search for efficient ligands prepared in only a few steps from inexpensive raw materials, easy to handle and that induce higher rates and substrate scope has therefore attracted the attention of many researchers. For this purpose two main strategies have been used for ligand design. One, developed recently by the groups of Oestrich and Zhou, illustrates the power of mixed phosphine-phosphine oxides which had been discarded in the Heck reaction for decades. $\mathrm{Pd} /$ phosphine-phosphine oxide systems were successfully applied in the intermolecular Heck reaction of several cyclic alkene substrates with various aryl triflates and aryl halides. ${ }^{[8]}$ The second strategy was based on biaryl phosphite-oxazoline ligands. Phosphite-containing ligands are particularly useful for asymmetric catalysis. ${ }^{.9]}$ They are modular, easy to synthesize from available alcohols and more resistant to oxidation than the phosphines. In this respect, an improved generation of air stable phosphite-oxazoline ligand libraries was developed. ${ }^{[10]}$ The application of two of these phosphite-oxazoline libraries in the Heck reaction led to identify a $\mathrm{Pd} /$ phosphite-oxazoline 7 catalyst (Figure 1) that provided conversions of $100 \%$ at $50{ }^{\circ} \mathrm{C}$ in $24 \mathrm{~h}$ with excellent regio- and enantioselectivities in the coupling of several cyclic substrates and a variety of aryl triflates. ${ }^{[1]}$ To the best of our knowledge no other phosphite-oxazoline ligands have been applied. Despite the mentioned developments, the use of the phosphite-oxazoline ligands in the intermolecular Heck reaction has several unknowns that must be explored to facilitate/accelerate the search for better catalysts. For example, no mechanistic studies have been made to discern the role of the ligand parameters that explain in a conclusive way the high activity of chiral phosphite-oxazoline ligands compared with their analogues phosphine- $\mathrm{N}$ ligands. ${ }^{[12]}$ In contrast to other $\mathrm{C}-\mathrm{C}$ bond forming reaction such as $\mathrm{Pd}$ TsujiTrost reactions, most of the mechanistic studies in Heck reaction have focused on achiral systems. ${ }^{[13]}$ In this respect, efficient and accurate kinetic studies have been reported that include the entire catalytic system. However, no kinetic studies have been carried out for the asymmetric version and the few mechanistic studies for specific chiral ligands are mainly computational. ${ }^{[40,5 g, 14]}$ Spectroscopic studies by NMR and kinetic studies are hampered by the high reactivity and multifaceted aggregation behaviour of the Pdprecursor that gives unreactive Pd black. The experimental protocol to prevent the formation of $\mathrm{Pd}$ black under reaction conditions must still be developed.

To address these points, we report the application of a reduced but structurally valuable library of readily accessible phosphite-oxazoline ligands L1-L5a-e (Figure 2). These were obtained by replacing the phosphino group $\mathrm{R}_{2} \mathrm{P}$ - in phosphine-oxazoline ligand $5^{[40]}$ by biaryl phosphite moieties (RO) $)_{2} \mathrm{PO}-$ thus increasing robustness and modularity and allowing a better control of the flexibility of the chiral pocket. ${ }^{[15]}$ In addition, these ligands are solids and stable to air and other oxidizing agents. In a simple two or four step-procedure, which starts from commercially available materials, (Scheme 2) several ligand parameters can be easily tuned to maximize the catalyst performance. With this ligand library we systematically investigated the effect of changing the oxazoline substituents $\left(\mathrm{Ph},{ }^{\mathrm{i}} \mathrm{Pr}\right.$ and $\left.{ }^{\mathrm{t}} \mathrm{Bu}\right)$ and their 
configuration, the substituents in the benzylic position (ligands L1-L3a-e with hydrogens and ligands L4a-e with methyl groups) and the substituents and configuration of the biaryl phosphite moiety (a-e). Interestingly, we found that the range of substrates and aryl and alkyl triflates that can be successfully coupled was larger than that for the previous phosphineoxazoline 5 counterparts, which have emerged as some of the most successful catalysts designed for this process. In addition, the phosphite-oxazoline ligands that provided the best selectivities contained the ${ }^{i} \mathrm{Pr}$ substituent in the oxazoline moiety instead of the costly ${ }^{\mathrm{t}} \mathrm{Bu}$ derivative found in the related phosphineoxazoline 5. Finally, in this paper we have also carried out kinetics studies and a Hammett plot analysis to determine the rate determining step. For this purpose we have successfully developed experimental conditions that disfavour the formation of Pd black from $\mathrm{Pd}$-intermediate species during the kinetic experiments.
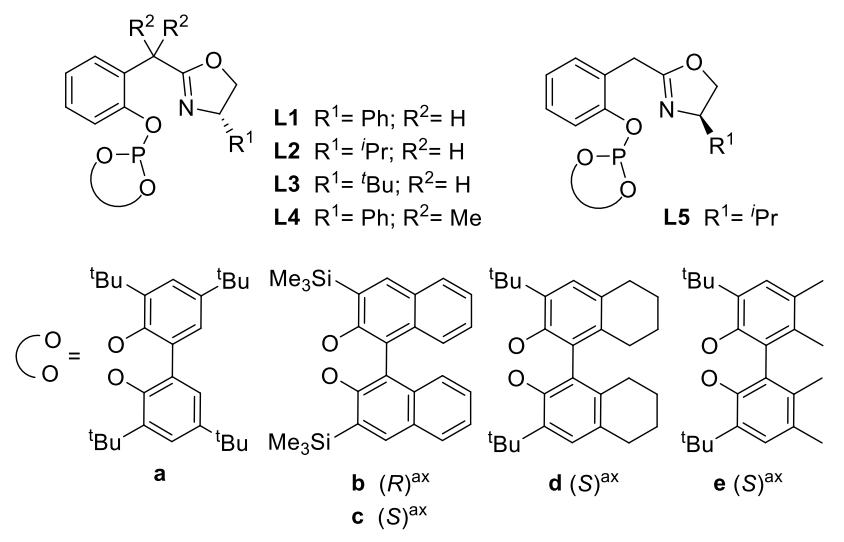

Figure 2. Phosphite-oxazoline ligand library L1-L5a-e.

\section{Results and Discussion}

\section{Synthesis of ligands}

The sequence of the ligand synthesis is illustrated in Scheme 2. Phosphite-oxazoline ligands L1-L3a-e and L5c were synthesized very efficiently in a two-step procedure as previously reported by our group from readily available starting materials. ${ }^{[15]}$ Therefore, coupling of hydroxyl-cyanide $\mathbf{8}$ with the appropriate amino alcohol yielded the hydroxyl-oxazolines 9-12 with diverse oxazoline substituents (Scheme 2, step i) ${ }^{[16]}$ Then, compounds 9-12 readily react with the corresponding phosphorochloridites $\left(\mathrm{ClP}(\mathrm{OR})_{2}(\mathrm{OR})_{2}\right.$ $=\mathbf{a}-\mathbf{e})$ to yield the desired phosphite-oxazoline ligands L1-L3a-e and L5a. For the synthesis of new phosphite-oxazoline ligands $\mathbf{L} 4$, which differs from L1-L3 in the presence of methyl groups on the benzylic position, the commercially available $2(3 H)$ benzofuranone 13 was converted into the corresponding benzofuranone $\mathbf{1 4}$ by treatment with methyl iodide and sodium hydride (step ii). ${ }^{[17]}$ Subsequent reaction of $\mathbf{1 4}$ with 3-amino-3phenylpropan-1-ol (amino alcohol) followed by cyclization with $p$-TsCl afforded the desired hydroxyloxazoline 15 (steps iii and iv). Finally, condensation of the desired in situ formed phosphorochloridites $\left(\mathrm{ClP}(\mathrm{OR})_{2}(\mathrm{OR})_{2}=\mathbf{a}-\mathbf{c}\right)$ with hydroxyl-oxazoline $\mathbf{1 5}$ yielded phosphite-oxazoline ligands L4a-c, with different biaryl phosphite groups.

All ligands were isolated as white solids in good-tohigh yields. As mentioned earlier, they can be manipulated and stored in air. Ligands were characterized by ${ }^{31} \mathrm{P}\left\{{ }^{1} \mathrm{H}\right\},{ }^{1} \mathrm{H}$ and ${ }^{13} \mathrm{C}\left\{{ }^{1} \mathrm{H}\right\}$ NMR spectra and mass spectrometry. All data were in agreement with assigned structures (see experimental and supporting information sections for details). The ${ }^{1} \mathrm{H},{ }^{13} \mathrm{C}$, and ${ }^{31} \mathrm{P}$ NMR spectra showed the expected pattern for these $C_{1}$-ligands. The VT-NMR spectra in $\mathrm{CD}_{2} \mathrm{Cl}_{2}\left(+35\right.$ to $-85^{\circ} \mathrm{C}$ ) for ligands L1-L4a showed only one isomer in solution.

\section{Asymmetric Heck reaction of 2,3-dihydrofuran (S1)}

We first applied the ligands L1-L5a-e to the Pdcatalyzed phenylation of 2,3-dihydrofuran S1. For comparison, ligands were evaluated using the optimal reaction conditions reported in our previous studies with other phosphite-oxazoline ligands. ${ }^{[1]}$ Reactions were thus performed in tetrahydrofuran, at $50{ }^{\circ} \mathrm{C}$, using $2.5 \mathrm{~mol} \%$ of in-situ generated catalyst, by mixing the $\left[\mathrm{Pd}_{2}(\mathrm{dba})_{3}\right] \cdot \mathrm{C}_{6} \mathrm{H}_{6}{ }^{[18]}$ with the corresponding chiral ligand, and ${ }^{1} \operatorname{Pr}_{2} \mathrm{NEt}$ as base. The results are collected in Table 1 . The catalytic performance was

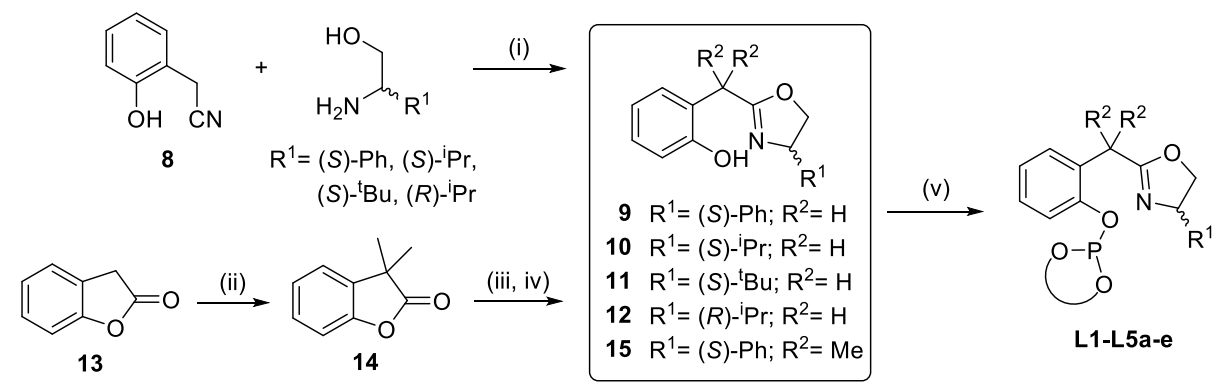

Scheme 2. Synthetic route for the synthesis of phosphite-oxazoline ligands L1-L5a-e. (i) amino alcohol, $\mathrm{ZnCl}_{2}, \mathrm{C}_{6} \mathrm{H}_{5} \mathrm{Cl}$, reflux, $16 \mathrm{~h}$ (yields $68-78 \%$ ); ${ }^{[16]}$ (ii) NaH, MeI, THF, $-78{ }^{\circ} \mathrm{C}$ to $\mathrm{rt}\left(43 \%\right.$ yield); ${ }^{[17]}$ (iii) Aminoalcohol, $\mathrm{NaH}, \mathrm{MeOH}, \mathrm{THF}, 0$ ${ }^{\circ} \mathrm{C}$ to rt, $4 \mathrm{~h}$, (75\% yield). (iv) $p$-TsCl, $\mathrm{NEt}$, DMAP, $\mathrm{CH}_{2} \mathrm{Cl}_{2}, 0{ }^{\circ} \mathrm{C}$ to rt, overnight $\left(89 \%\right.$ yield). (v) $\mathrm{ClP}(\mathrm{OR})_{2}\left((\mathrm{OR})_{2}=\mathbf{a}-\mathbf{e}\right)$, Py, toluene at $\mathrm{rt}$ for $18 \mathrm{~h}$ ( $40-78 \%$ yields). 
found to depend on the ligand structure, i.e., the substituents on the oxazoline ring and on the benzylic position and the substituents/configuration of the biaryl phosphite moiety.

Table 1. Pd-catalyzed enantioselective phenylation of 2,3dihydrofuran S1 using ligands L1-L5a-e. ${ }^{\mathrm{a}}$

\begin{tabular}{|c|c|c|c|}
\hline Fntry & & $\frac{1}{0 / \operatorname{Cony}^{-1 \cdot 2)^{b}}}$ & $\frac{2}{0 / 0 e e 1^{c}}$ \\
\hline 1 & L1a & $94(98: 2)$ & $67(R)$ \\
\hline 2 & L1b & $50(52: 48)$ & $81(R)$ \\
\hline 3 & L1c & $92(99: 1)$ & $75(R)$ \\
\hline 4 & L2a & $100(97: 3)^{d}$ & $90(R)$ \\
\hline 5 & L2b & $42(58: 42)$ & $47(S)$ \\
\hline 6 & L2c & $97(96: 4)$ & $71(R)$ \\
\hline 7 & L2d & $99(98: 2)^{\mathrm{e}}$ & $92(R)$ \\
\hline 8 & L2e & $88(97: 3)^{f}$ & $92(R)$ \\
\hline 9 & L3a & $20(44: 56)$ & $85(R)$ \\
\hline 10 & L3b & $47(43: 54)$ & $10(S)$ \\
\hline 11 & L3c & $85(96: 4)$ & $81(R)$ \\
\hline 12 & L4a & $48(20: 80)$ & $4(R)$ \\
\hline 13 & L4b & $5(45: 55)$ & $15(R)$ \\
\hline 14 & L4c & $13(43: 57)$ & $20(R)$ \\
\hline 15 & L5a & $100(96: 4)^{\mathrm{g}}$ & $90(S)$ \\
\hline $16^{\mathrm{h}}$ & L2a & $6(89: 11)$ & $78(R)$ \\
\hline $17^{\mathrm{i}}$ & L2a & $100(97: 3)$ & $85(R)$ \\
\hline $18^{\mathrm{j}}$ & L2a & $64(87: 13)$ & $71(R)$ \\
\hline
\end{tabular}

${ }^{\mathrm{a}}\left[\mathrm{Pd}_{2}(\mathrm{dba})_{3}\right]$.benzene $\left(1.25 \cdot 10^{-2} \mathrm{mmol}\right), \mathbf{S 1}(2.0 \mathrm{mmol})$, phenyl triflate $(0.5 \mathrm{mmol})$, ligand $\left(2.8 \cdot 10^{-2} \mathrm{mmol}\right)$, THF (3 $\mathrm{ml}),{ }^{i} \mathrm{Pr}_{2} \mathrm{NEt}(1 \mathrm{mmol}), 50{ }^{\circ} \mathrm{C}, 24 \mathrm{~h} .{ }^{\mathrm{b}}$ Conversion percentages determined by GC. ${ }^{\mathrm{c}}$ Enantiomeric excesses measured by GC. ${ }^{\mathrm{d}} 89 \%$ isolated yield. ${ }^{\text {e }} 86 \%$ isolated yield. f $71 \%$ isolated yield. ${ }^{\mathrm{g}} 87 \%$ isolated yield. ${ }^{\mathrm{h}}$ Reaction carried out at $23{ }^{\circ} \mathrm{C}$. ${ }^{\mathrm{i}}$ Reaction carried out at $70{ }^{\circ} \mathrm{C}$. ${ }^{\mathrm{j}}$ Reaction carried out in benzene.

The reactions that proceeded with the highest activities, regio- and enantioselectivities (e.g. entries 4-6 vs 1-3 and 9-11) all have ligands containing the ${ }^{i} \mathrm{Pr}$ oxazoline group (ligands L2). This contrasts with the oxazoline-substituent effect observed in the vast majority of successful phosphine-oxazoline ligands (such as the ${ }^{t}$ BuPHOX 3 and the Gilberston phosphineoxazoline ligand based on ketopinic acid 4; see Figure 1) the enantioselectivities of which are higher when tert-butyl groups are present. Interestingly, by comparing the results with those from the analogous Pd-phosphine-oxazoline systems $5^{[40]}$ (Figure $1, \mathrm{R}=\mathrm{H}$ ) it was found that the simple substitution of the phosphine by biaryl phosphite groups is advantageous since the ligands that provided the best selectivities contained the ${ }^{i} \mathrm{Pr}$ substituent in the oxazoline moiety instead of the costly ${ }^{\mathrm{t}} \mathrm{Bu}$ derivative. As expected, the sense of enantioselectivity is governed by the absolute configuration of the oxazoline substituent (entry 4 ligand L2a vs entry 15 ligand L5a). Both enantiomers of the phenylation product 1 can therefore be accessed by simply changing the absolute configuration of the oxazoline group.
The introduction of methyl groups at the benzylic position had a negative effect on both activity and selectivity (Table 1, entries 12-14 vs 1-3). This contrasts with the results reported for related phosphine-oxazoline $\mathbf{5}^{[4 \mathrm{o}]}$ where the introduction of Me substituents at the benzylic position provided the reverse enantiomer although with somewhat lower enantioselectivity (from $93 \%(R)$ with a $\mathrm{H}$ substituent to $81 \%(S)$ with a Me substituent) and regioselectivity.

Finally, concerning the effect of the biaryl phosphite group, we found that its configuration affected activity and selectivity. In general, ligands with an $S$ configuration of the biaryl phosphite moiety provided higher conversion, regio- and enantioselectivities than ligands with an $R$-configuration (Table 1 , entries 6-8 vs 5) although ligand L2a with the aquiral biaryl phosphite group also provided high activities and selectivities (Table 1, entry 4). This ligand maintains the economic benefits of using an ${ }^{i} \mathrm{Pr}$ oxazoline substituent and has the added advantage that an achiral inexpensive biaryl phosphite moiety a is used. By comparing the results of $\mathbf{L} \mathbf{2} \mathbf{a}$ with those of the related enantiopure biaryl ligands L2b and L2c, (entry 4 vs 5 and 6), it can be concluded that the tropoisomeric biphenyl moiety in L2a adopts an $S$-configuration. The results also show that the substituent of the biaryl phosphite moiety has an important effect on selectivity since ligands L2d-e provided higher selectivity than L2c (entries 7-8 vs 6).

In an attempt to prove that the tropoisomerism of the achiral biphenyl phosphite can be controlled by the ligand backbone upon coordination to $\mathrm{Pd}$ and also to rationalize the lower enantioselectivities with ligands L2b and L2c than those obtained with ligands L2a,de, we investigated the coordination ability of ligands L2a-c,e. For that purpose, the corresponding $[\mathrm{Pd}(\mathrm{I})(\mathrm{Ph})(\mathbf{L})](\mathbf{L}=\mathbf{L} \mathbf{2 a - c}, \mathbf{e})$ neutral complexes 16-19 were prepared. These complexes were prepared by reaction of $[\mathrm{Pd}(\mathrm{I})(\mathrm{Ph})(\mathrm{TMEDA})]$ (TMEDA= $\mathrm{N}, \mathrm{N}, \mathrm{N}, \mathrm{N}$-tetramethylethlendiamine) with one equivalent of the corresponding ligands (Scheme 3).

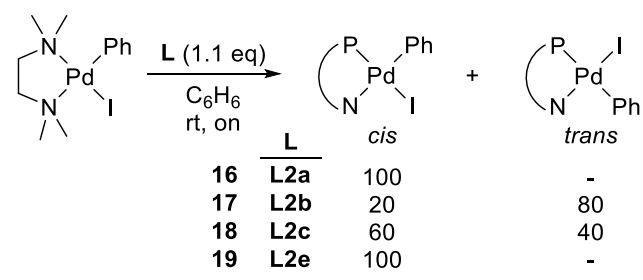

Scheme 3. Preparation of $[\mathrm{Pd}(\mathrm{I})(\mathrm{Ph})(\mathbf{L})] \quad(\mathbf{L}=\mathbf{L} 2 \mathbf{a}-\mathbf{c}, \mathbf{e})$ neutral complexes. The ratio of each isomer measured by ${ }^{31} \mathrm{P}-\mathrm{NMR}$ spectroscopy is also shown.

For complex 16, containing tropoisomeric ligand L2a, only one isomer was detected by VT-NMR (30 ${ }^{\circ} \mathrm{C}$ to $-80^{\circ} \mathrm{C}$ ) which has been assigned to the $\mathrm{cis}$ isomer (Scheme 3). In contrast, for complexes containing ligands L2b and L2c (compounds 17 and 18) the two isomers cis and trans were observed (Scheme 3). The minor isomer of $[\mathrm{Pd}(\mathrm{I})(\mathrm{Ph})(\mathbf{L} 2 \mathbf{b})]$ and the major isomer of $[\mathrm{Pd}(\mathrm{I})(\mathrm{Ph})(\mathbf{L} \mathbf{2 c})]$ were assigned to the cis 
isomers. Finally, coordination of ligand $\mathbf{L 2 e}$, led to the formation of cis-[Pd(I)(Ph)(L2e)] (19) exclusively, as in the case of tropoisomerically labile ligand L2a. All these results, therefore, support the conclusion that the flexible biphenyl phosphite moiety in ligand L2a adopts an $S$-configuration upon coordination to $\mathrm{Pd}$. In addition, the presence of a mixture of isomers upon coordination of ligands $\mathbf{L 2 b}$ and L2c (with trimethylsilyl groups at the ortho positions of the binaphthyl phosphite moiety), may explain the lower enantioselectivities achieved using $\mathrm{Pd} / \mathbf{L} 2 \mathbf{b}-\mathbf{c}$, in the phenylation of S1, than those with ligands L2a,d-e (containing tert-butyl groups, see Table 1 , entries 4,7 and 8 vs 5 and 6 ).

All complexes were characterized by ${ }^{1} \mathrm{H},{ }^{13} \mathrm{C}$ and ${ }^{31} \mathrm{P}$ NMR spectroscopy and HR-mass spectrometry. The spectral assignments were confirmed using ${ }^{1} \mathrm{H}-{ }^{1} \mathrm{H},{ }^{31} \mathrm{P}-$ ${ }^{1} \mathrm{H},{ }^{13} \mathrm{C}-{ }^{1} \mathrm{H},{ }^{1} \mathrm{H}-{ }^{-1} \mathrm{H}$ NOESY and ${ }^{31} \mathrm{P}$ DOSY experiments. Therefore, the ${ }^{31} \mathrm{P}$ DOSY spectra for both isomers of complexes with ligands $\mathbf{L} \mathbf{2 b}$ and $\mathbf{L} \mathbf{2 c}$, show the same diffusion coefficients. Both isomers also show the same HR-mass spectra. All this agrees with the presence of the two possible isomers, cis and trans. The cis disposition of complexes with ligands L2a, L2d and the minor isomer of $[\mathrm{Ph}(\mathrm{I})(\mathrm{Ph})(\mathbf{L} 2 \mathbf{b})]$ and major isomer of $[\mathrm{Pd}(\mathrm{I})(\mathrm{Ph})(\mathbf{L} \mathbf{2 c})]$ has been clearly established by the small carbon-phosphorus coupling constant observed for the $\mathrm{C}_{\text {ipso }}$ of the phenyl ligand $\left(J_{\mathrm{C}}\right.$ $\mathrm{p}<20 \mathrm{~Hz}$ ). For the trans isomers the NOESY shows NOE interactions between the isopropyl substituent of the oxazoline group and some of the aromatic protons of the phenyl ligand.

In summary, the highest regio- (up to 98\%) and enantioselectivities (up to $92 \%$ ) were achieved with phosphite-oxazoline ligands L2a,d-e and L5a. We next studied the effect of the temperature with one of the best ligands (entries 16, 17). Lowering the temperature to $23{ }^{\circ} \mathrm{C}$ has a negative effect on both selectivity and activity (only $6 \%$ of conversion after two days). High temperature $\left(70{ }^{\circ} \mathrm{C}\right)$ has also a negative effect on enantioselectivity whereas the good selectivity in favour of compound $\mathbf{1}$ is maintained. Finally, we studied the effect of changing the solvent to benzene. Most of the successful ligands reported in the literature gave better catalytic performance using benzene instead of THF. ${ }^{[3]}$ This was not the case; activities and selectivities were lower in benzene (entry 18).

Other aryl and alkyl triflates. We next studied other aryl and alkyl triflates. The results follow the same trend, in terms of the effect of the ligand parameters, as the phenylation of S1. Again, the best results were obtained with L2a,d,e and L5a. As an example, Scheme 4 shows the results using ligand L2d which had provided one of the best results in the phenylation of S1 (the full results are shown in the Supporting Information). Both enantiomers of the coupling products 1a-h were accessible with high activity, regio- (up to 99\%) and enantioselectivity (up to 98\%). Improving results reported in the literature, it was found that the catalytic performance was hardly affected by the steric and electronic properties of the aryl groups. Therefore, a variety of triflates with different electronic and steric properties (1- and 2naphthyl, $p-\mathrm{CH}_{3}-\mathrm{C}_{6} \mathrm{H}_{4}, p-\mathrm{NO}_{2}-\mathrm{C}_{6} \mathrm{H}_{4}, p-\mathrm{OMe}-\mathrm{C}_{6} \mathrm{H}_{4}$ and $o$-OMe- $\left.\mathrm{C}_{6} \mathrm{H}_{4}\right)$ reacted with $\mathbf{S 1}$ in regio- and enantioselectivities as high as or higher than those obtained with phenyl triflate. Even the sterically demanding 1-naphthyl and $o$-methoxyphenyl triflates were cross-coupled efficiently (products $\mathbf{1 f}$ and $\mathbf{1 g}$ ). Finally, it is also worth mentioning that the addition of cyclohexenyl triflate that usually reacted with less regio- and enantioselectively than the coupling of phenyl triflate proceeded with comparable high regioand enantioselectivity. All these results are among the best that have been reported in the literature $e^{[1 \mathrm{c}, \mathrm{n}]}$ and surpass the range of aryl and alkyl triflates that could be coupled with the phosphine-oxazoline analogues $5^{[40]}$.

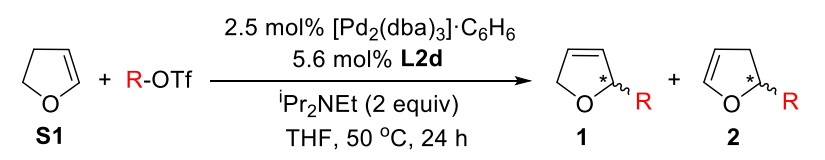

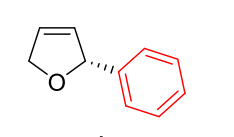

$1 \mathrm{a}$

$99 \%$ Conv
$98 \%$ regio $92 \%(R)$ ee

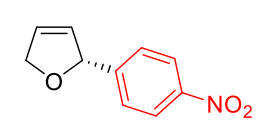

1d

$99 \%$ Conv

$99 \%$ regio

$97 \%(R)$ ee
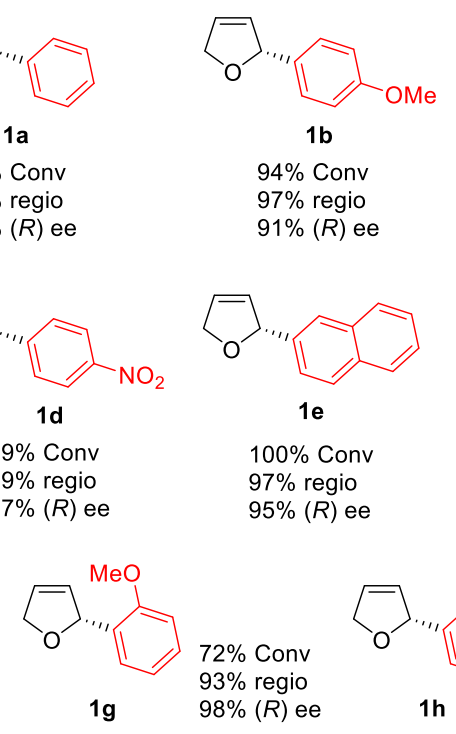

$1 \mathrm{~b}$

$94 \%$ Conv $97 \%$ regio $91 \%(R)$ ee

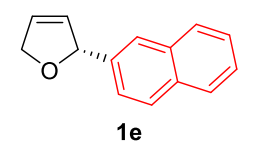

$100 \%$ Conv $97 \%$ regio $95 \%(R)$ ee

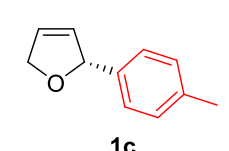

1c

$94 \%$ Conv $97 \%$ regio $93 \%(R)$ ee

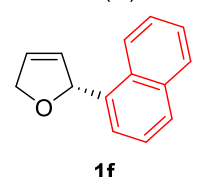

$89 \%$ Conv $99 \%$ regio $98 \%(R)$ ee
Scheme 4. Asymmetric Heck reaction of 2,3-dihydrofuran S1.

\section{Asymmetric Heck reaction of other substrates}

The potential of L1-L5a-e ligands was further studied by using them in the Pd-catalyzed Heck reaction of other challenging substrates. Initially the arylation of 4,7-dihydro-1,3-dioxepin S2 with phenyl- and $p$-tolyl triflates was studied (Scheme 5a). The enol ethers 20 resulting from these substrate are easily converted into chiral $\beta$-aryl- $\gamma$-butyrolactones, which are useful synthetic intermediates. ${ }^{[19]}$ Despite its relevance, successful examples in literature are scarce and most of them require long reaction times for full conversion. ${ }^{[20]}$ The results are summarized in Scheme $5 \mathrm{a}$ and followed the same trends as for the arylation of S1. Again, catalysts $\mathrm{Pd} / \mathbf{L} 2 \mathbf{a}, \mathbf{d}-\mathbf{e}$ and $\mathrm{Pd} / \mathbf{L} 5 \mathbf{a}$ provided 
both enantiomers of the arylation products 20a and 20b in high enantioselectivities (up to 95\%) comparable to the best reported so far (see Supporting Information for complete set of results).

Dihydropyrroles are another important set of substrates which are widely present in biological compounds and have versatile synthetic applications. ${ }^{[21]}$ Therefore, the asymmetric Heck reaction of $N$-Boc-2,3-dihydropyrrole $\mathbf{S 3}$ with phenyl and $p$-tolyl triflates was investigated (Scheme $5 \mathrm{~b}$ ). So far, only a few examples have been reported. ${ }^{[1]}$ Again, ligands L2a,d,e and L5a that contain the ${ }^{i} \mathrm{Pr}$ substituent in the oxazoline moiety (see the complete results in the Supporting Information) provided the best results with activities, regio- (up to 98\%) and enantioselectivities (up to 94\%) comparable to the best ones reported in the literature. ${ }^{[1]}$

(a)

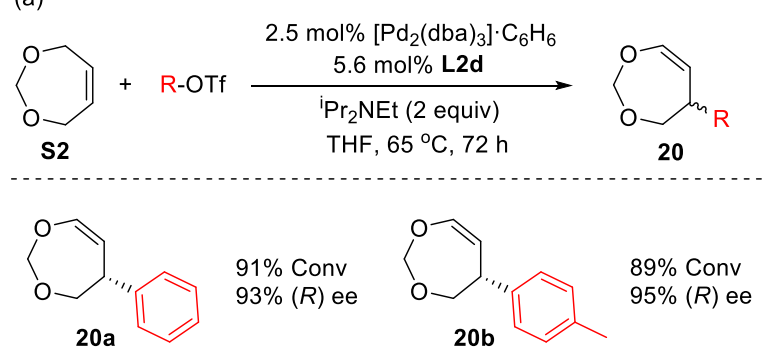

(b)

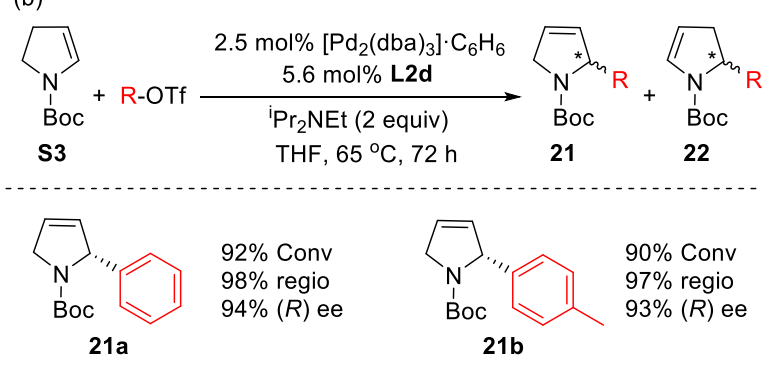

Scheme 5. Asymmetric Heck reaction of (a) 4,7-dihydro1,3-dioxepin $\mathbf{S 2}$ and (b) N-Boc-2,3-dihydropyrrole $\mathbf{S 3}$.

Finally the attention was turned to the asymmetric alkenylation of cyclopentene S4 (Scheme 6). Due to extensive double-bond displacement, the selectivity is more difficult to control in this substrate than in functionalized alkenes, such as S1 and S3. ${ }^{[1]}$ Most of the catalysts fail to control the regioselectivivity and, in addition to the desired product $\mathbf{2 3}$, the corresponding achiral regioisomers 24 and 25 can be obtained ${ }^{\left[{ }^{[1]}\right.}$ Catalytic systems $\mathrm{Pd} / \mathbf{L} \mathbf{2 a}, \mathbf{d}-\mathbf{e}$ and $\mathrm{Pd} / \mathbf{L 5 a}$ turned out to be efficient in the alkenylation of $\mathbf{S 4}$ using four aryl triflates with different electronic and steric proprieties (Scheme 5 and Supporting Information for full set of results). In all cases high activities, regio- and enantioselectivities in both enantiomers of the arylation products 23a-d were achieved without the formation of the undesired achiral product 25.
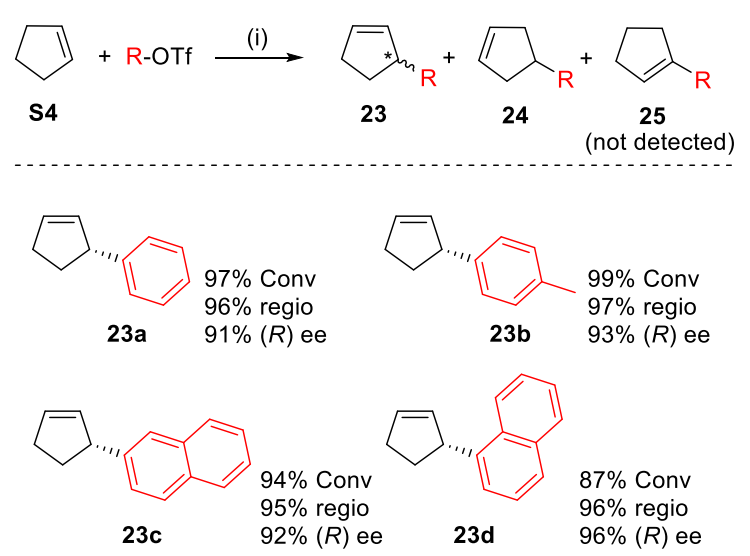

Scheme 6. Asymmetric Heck reaction of cyclopentene $\mathbf{S 4}$. (i) $2.5 \mathrm{~mol} \%\left[\mathrm{Pd}_{2}(\mathrm{dba})_{3}\right] \cdot \mathrm{C}_{6} \mathrm{H}_{6}, 5.6 \mathrm{~mol} \% \mathrm{L2d},{ }^{\mathrm{i}} \mathrm{Pr}_{2} \mathrm{NEt}(2$ equiv), THF, $50{ }^{\circ} \mathrm{C}, 48 \mathrm{~h}$.

In summary, the replacement of the phosphine by a phosphite group in the phosphine-oxazoline ligands $\mathbf{5}$ provided air stable ligands which in addition extended the range of substrates and aryl and alkyl triflates that could be successfully coupled with regio-, enantioselectivities and activities that were among the few best reported so far. ${ }^{[1]}$ In addition, the ligands that provided the best enantioselectivities contained the ${ }^{i} \mathrm{Pr}$ substituent in the oxazoline moiety instead of the ${ }^{\mathrm{t}} \mathrm{Bu}$ substituent leading to a cost reduction.

Asymmetric Heck reaction of 2,3-dihydrofuran with aryl halides

Carbon electrophiles in the asymmetric intermolecular Heck reaction have been mostly restricted to aryl or vinyl triflates. To date, only a few successful examples using aryldiazonium salts, ${ }^{[\mathrm{hh}, 22]}$ arylboronic acids ${ }^{[23]}$ and benzylic electrophiles ${ }^{[24]}$ and one using aryl halides ${ }^{[8 d]}$ have been reported. With aryl halides, mixed phosphine-phosphine oxide ligands were found to be the best choice whilst BINAP and ${ }^{\mathrm{t}} \mathrm{Bu}-\mathrm{PHOX}$ provided very low activities $(<10 \%)$ and BINAP also extremely low enantioselectivity $(<5 \%$ ee $) .{ }^{[8 \mathrm{~d}]}$ The success of this transformation also required the addition of 1 equiv. of additive (mainly $p$ - $\mathrm{NO}_{2} \mathrm{PhCO}_{2} \mathrm{H}$ although silver salts such as AgOTf were also used) and ethylene glycol or methanol as solvents (the more common toluene, ether and 1,4 dioxane led to poor results). In addition, most of the electrophiles were aryl bromides and only a few were ArCl. Aryl iodides gave not only lower enantioselectivity but also a shift to the preferential formation of regiosomer 2 (i.e., the phenylation of $\mathbf{S 1}$ afforded 1 and 2 at a 1:2 ratio). ${ }^{[8 d]}$ Under these reaction conditions, we tested whether ligands L1-L5a-e could do the desired coupling (Scheme 7). The reaction of $\mathbf{S 1}$ with phenyl bromide provided the desired regioisomer 1 as a major product in high enantioselectivity $(87 \%$ ee), albeit with low conversion. The use of phenyl iodide led to similar levels of enantioselectivities although the formation of isomer $\mathbf{2}$ is favored. 


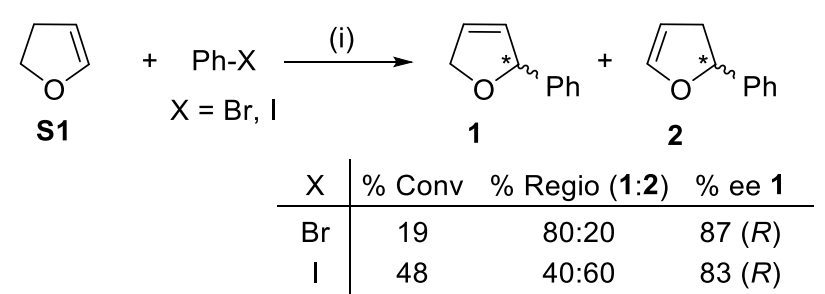

Scheme 7. Asymmetric Heck reaction of S1 with aryl halides. (i) $2.5 \mathrm{~mol} \%\left[\mathrm{Pd}_{2}\left(\mathrm{dba}_{3}\right] \cdot \mathrm{C}_{6} \mathrm{H}_{6}, 3 \mathrm{~mol} \%\right.$ L2a, ${ }^{\mathrm{i}} \mathrm{Pr}_{2} \mathrm{NEt}$ (3 equiv), AgOTf (1.5 equiv), ethylene glycol, 80 ${ }^{\circ} \mathrm{C}, 24 \mathrm{~h}$.

\section{Kinetic studies and Hammett plot analysis}

There are no mechanistic studies that give a conclusive reason why the chiral phosphite-oxazoline ligands give a higher activity than most of the phosphineoxazolines. ${ }^{[1]]}$ Old studies $(<2000)$ on achiral systems mostly containing an excess of $\mathrm{PPh}_{3}$ or dba reported evidence for the oxidative addition as the rate-limiting step in this chemistry, which in the present case would have led to a faster reaction of the phosphine analogues. ${ }^{[25]}$ Since then kinetic studies using achiral monophosphite ligands ${ }^{[13 \mathrm{a}, \mathrm{e}]}$ and studies using metallocyclic phosphine and imine precursors ${ }^{[13 b, \mathrm{c}]}$ showed that the rate determining step in those systems is the alkene coordination or the migratory insertion of the alkene, the migratory insertion being the most plausible choice as tentatively suggested by further electronic alkene effects. ${ }^{[13 a, e]}$

We decided to perform a brief kinetic study under practical conditions to determine the rate determining step in the reactions of the $\mathrm{Pd} /$ phosphite-oxazoline catalysts reported in this manuscript. To achieve this goal first a viable catalyst precursor was synthesized and new reactions conditions were developed to prevent the formation of Pd black. Scheme 8 presents the generally accepted mechanism for the Heck coupling reaction that served as the basis for the kinetic study (all steps shown as reversible). The catalytic cycle is initiated by the oxidative addition of phenyl triflate to the $\mathrm{Pd}(0)-\mathrm{PN}^{*}$ complex resulting in the four coordinate aryl-Pd(II) complex which then reacts with the olefin to form the $\pi$-complex. Insertion of the olefin into the Pd-Ph bond leads to a Pd-alkyl species which undergoes $\beta$-hydride elimination, followed by dissociation to the product and a Pdhydride complex. The catalytic cycle is completed by base-assisted reductive elimination of HOTf regenerating the catalytically active $\operatorname{Pd}(0)$ complex.

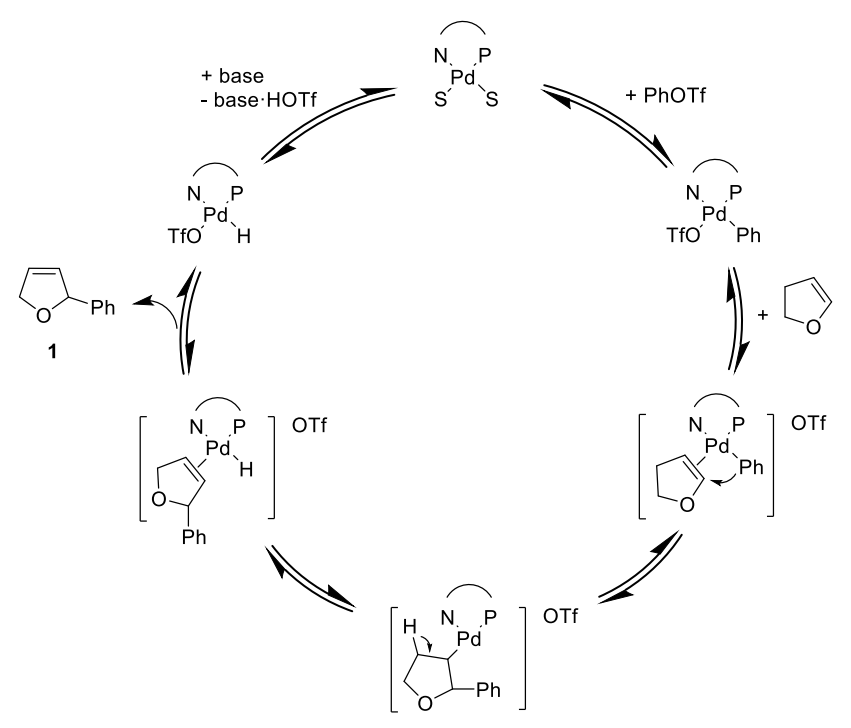

Scheme 8. Accepted mechanism for the asymmetric Pdcatalyzed Heck reaction of $\mathbf{S 1}$.

$[\mathrm{Pd}(\mathrm{Ph})(\mathrm{OTf})(\mathbf{L} 2 \mathbf{2})] \mathbf{2 6}$ was used as a viable catalyst precursor for the kinetic study. The use of $\mathrm{Pd}_{2}(\mathrm{dba})_{3} / \mathbf{L} 2 \mathbf{a}$ or its $[\mathrm{Pd}(\mathrm{dba})(\mathbf{L} 2 \mathbf{a})]$ analogues was discarded because the active species form too slowly under the employed conditions. ${ }^{[26]}$ Complex 26 was synthesized from the corresponding compound $[\mathrm{Pd}(\mathrm{I})(\mathrm{Ph})$ L2a) $]$ (16) by iodine abstraction with AgOTf (Scheme 9). Complex 26 was characterized by ${ }^{31} \mathrm{P},{ }^{1} \mathrm{H}$ and ${ }^{13} \mathrm{C}$ NMR spectroscopy. The VT-NMR experiments $\left(-78\right.$ to $\left.30^{\circ} \mathrm{C}\right)$ indicated the formation of a single stereoisomer. This is in agreement with the atropoisomerism of the biphenyl phosphite moiety being controlled by the ligand backbone upon coordination to the Pd-centre observed in Table 1 (vide supra). ${ }^{[27]}$ The NMR data also indicated that, as previously observed for other P,N-containing complexes, the phenyl ligand is located cis to the phosphite moiety. ${ }^{[5]}$ To prove the viability of $\mathbf{2 6}$ as a catalyst precursor, we first performed the stoichiometric reaction by adding 2 equivalents of $\mathbf{S 1}$ and an excess of base. The regio- and enantioselectivity achieved were similar to those achieved using the catalytic conditions (95\% regioselectivity and $88 \%$ ee), which clearly indicated that $[\mathrm{Pd}(\mathrm{Ph})(\mathrm{OTf})(\mathbf{L 2 a})]$ is a viable intermediate.

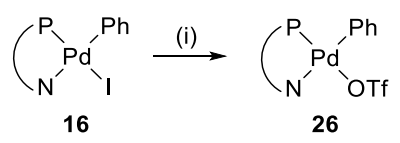

Scheme 9. Preparation of $[\mathrm{Pd}(\mathrm{Ph})(\mathrm{OTf})(\mathrm{L2a})]$ (26). (i) AgOTf, THF ( $90 \%$ yield).

Prior to the kinetic studies we performed a control experiment to study the stability of compound $\mathbf{2 6}$ under catalytic conditions monitoring the reaction during $24 \mathrm{~h}$. Unfortunately, deactivation of the molecular system was observed after 10-15 minutes, due to the formation of an inactive black precipitate. 
This contrasts with the stability observed in the catalytic runs using $\left[\mathrm{Pd}_{2}(\mathrm{dba})_{3}\right] / \mathbf{L} \mathbf{1}-\mathbf{L 5 a}-\mathbf{e}$ catalytic precursors (see vide supra) and this suggests that the presence of $\mathrm{dba}$ (although it does not participate in the catalytic cycle) and/or the excess of ligand are necessary to stabilize the molecular $\operatorname{Pd}(0)$ species thus preventing the formation of the inactive Pd precipitate. It was found that the addition of $12 \mathrm{~mol} \%$ of excess of ligand prevents the deactivation of the molecular system. Thus, the precipitation of Pd was not observed during the first 12 hours.

With the appropriate reaction conditions in hand the kinetic studies were performed using a simple approach $^{[28]}$, in which the concentration of each of the reagents involved was varied and the reaction rate measured after $1 \mathrm{~h}\left(\mathrm{TOF}_{\text {ini }}\right){ }^{\left[{ }^{[2]}\right.}$ Rates were plotted versus the concentrations (Figure 3 ). The rate of the reaction between $\mathbf{S} 1$ and phenyl triflate catalyzed by Pd-complex 26 was independent of the concentration of N,N-diisopropylethylamine (0.16-2.7 M; Figure $3 \mathrm{a}$ ) and phenyl triflate (0.16-2 M; Figure $3 \mathrm{~b})$. The zero order dependence in phenyl triflate agrees with a rapid oxidative addition. The independence of the reaction rate on the concentration of N,Ndiisopropylethylamine agrees with the fact that the elimination/reduction steps, that are base-assisted, are also fast. The effect of the Pd loading (2-16 mM) on the activity (Figure 3c) indicates a first orderdependency, because the rate of product formation is proportional to the $\mathrm{Pd}$ concentration. This is in contrast with the involvement of dimeric species reported for monodentate ligands (including phosphites). ${ }^{[13 a-e]}$
Finally, the kinetic study shows a linear dependence of the initial turn-over frequency $\left(\mathrm{TOF}_{\text {ini }}\right)$ on alkene concentration (Figure 3d). The first-order rate dependence on the alkene concentration clearly shows that the substrate is involved in the turn-over limiting step, either directly or in a pre-equilibrium. According to Scheme 8 this implies that either the alkene coordination to $\mathrm{Pd}$ or the subsequent insertion into the $\mathrm{Pd}-\mathrm{Ph}$ bond must be the turn-over limiting step. These two steps cannot be distinguished from the kinetic results described so far. To analyse this in more detail, we next determined the initial reaction rates with several para-substituted phenyl triflates ( $p$-R$\mathrm{C}_{6} \mathrm{H}_{4} \mathrm{OTf} ; \mathrm{R}=\mathrm{OMe}, \mathrm{Me}, \mathrm{H}, \mathrm{NO}_{2}$ ) using Pd-complex 26 under the same reaction conditions. The Hammett plot (Figure 4) shows a linear correlation between the Hammett $\sigma$ value and the relative reaction rates, ${ }^{[30]}$ with a negative $\rho$ value $(\rho=-0.89)$. Thus, the use of electron-withdrawing aryl triflates led to lower reaction rates, exhibiting the order $p-\mathrm{NO}_{2}<p-\mathrm{H}<p$ $\mathrm{Me}<p$-OMe. Both rate and equilibrium constant of the alkene coordination are only slightly affected by the electron donicity of the aryl group as it is in a cis position; besides the reverse order would have been expected. Thus the Hammett plot is not in line with a rate-limiting alkene coordination step. Migration of the aryl group, however, is known to be enhanced by increasing electron density on the migrating group, ${ }^{[31]}$ which is in agreement with the observed Hammett relation. Thus, we conclude that the migratory insertion is the rate-limiting step.
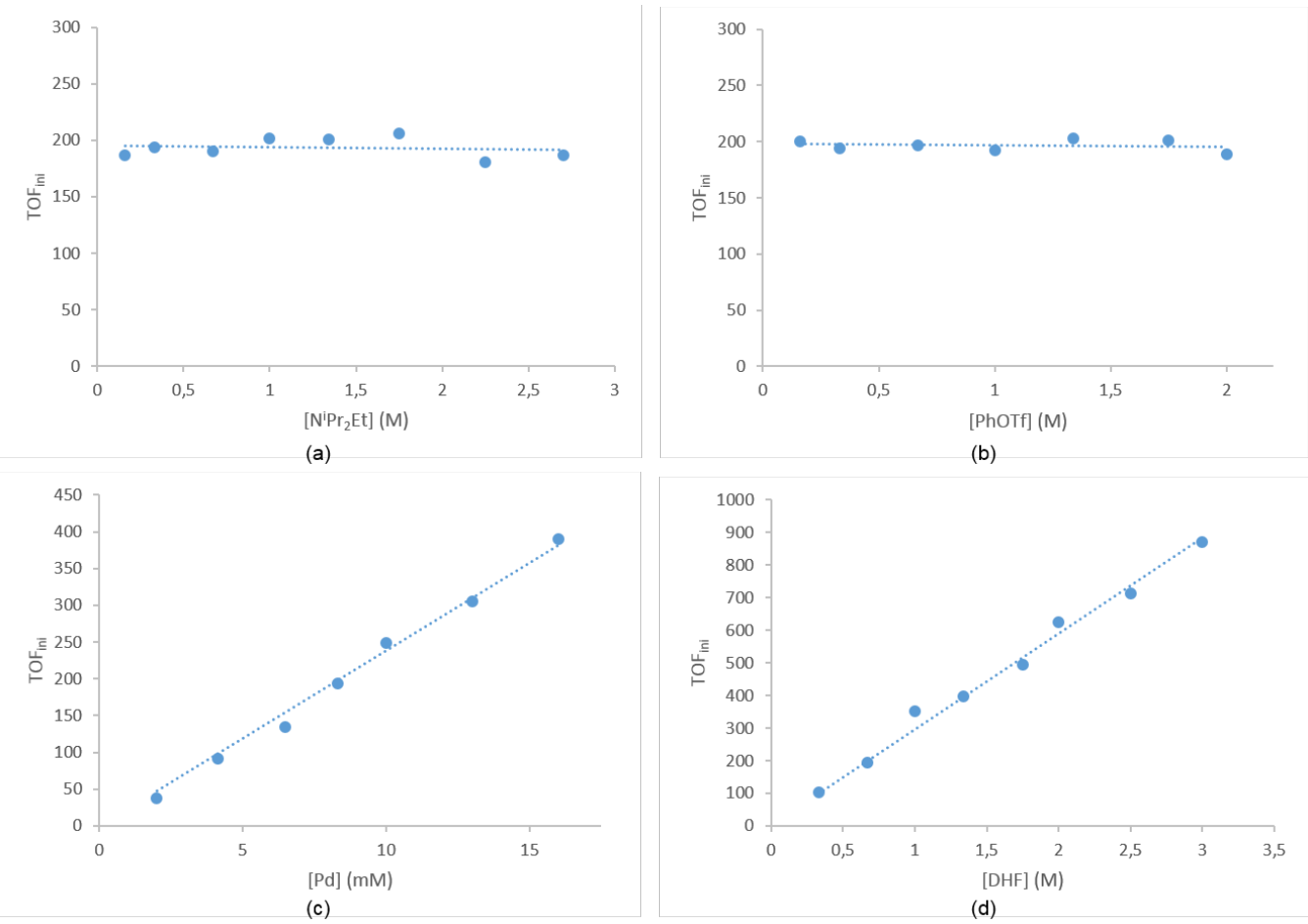

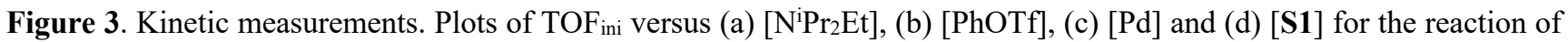
S1 with PhOTf in THF at $50^{\circ} \mathrm{C}$ catalyzed by complex $[\mathrm{Pd}(\mathrm{Ph})(\mathrm{OTf})(\mathbf{L 2 a})]$. TOF ini measured after $1 \mathrm{~h}$ (conversions typically of $5-10 \%)$. 


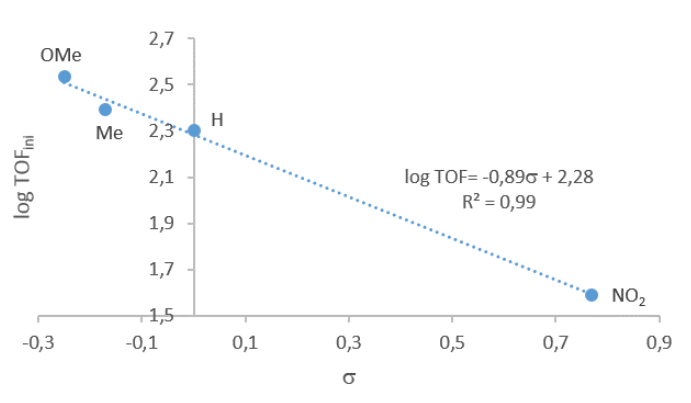

Figure 4. Hammet plot showing the effect of substituents on the Heck reaction using catalytic system $\mathrm{Pd} / \mathbf{L} \mathbf{2 a}$.

We return to the question why phosphite-oxazolines give faster catalysts than phosphine-oxazolines. Assuming that in the two related ligand groups the mechanism remains the same, the electronwithdrawing phosphites will raise the alkene-Pd adduct concentration (27a in Scheme 10 and species 4-o' clock in Scheme 8) and thus this will increase the rate of reaction, other things being equal. However, migratory insertion in palladium complexes containing non-symmetric bidentates is a complicated process. ${ }^{[32]}$ As shown in Scheme 10 a slow migratory insertion may take place in the alkene adduct 27a (Schemes 8 and 10) or this intermediate may first isomerize to the more reactive isomer $\mathbf{2 7} \mathbf{b}$, as found before for a small number of examples ${ }^{[33]}$. In the absence of more data we refrain from speculations on these details and propose that the higher rate for phosphite catalysts is caused by the higher population of alkene adducts $\mathbf{2 7} \mathbf{a}-\mathbf{b}$ as stated above and depictured in Scheme 10.

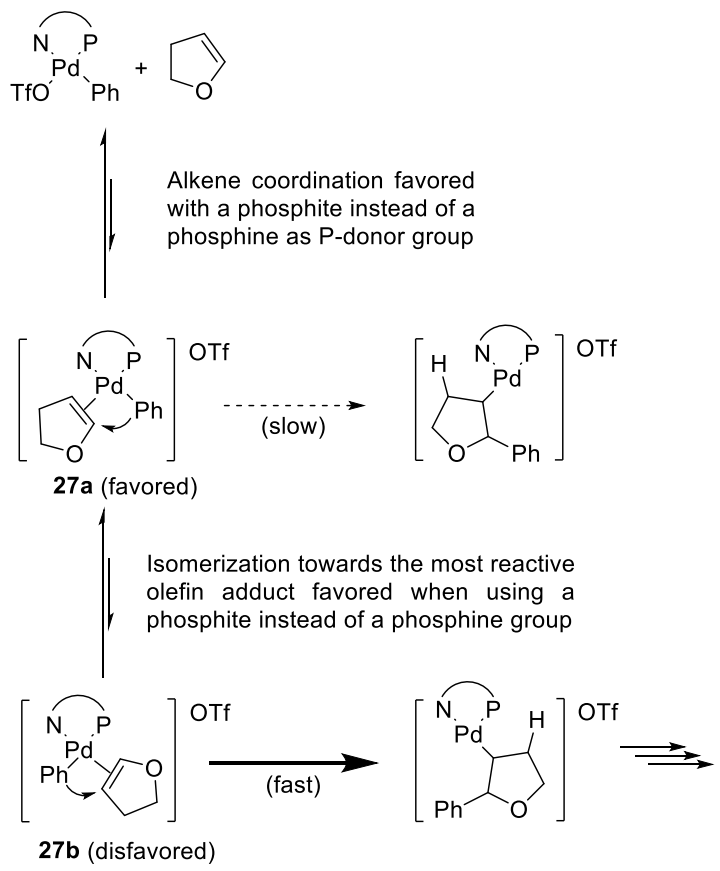

Scheme 10. Olefin coordination and migratory insertion pathways leading to the products.

\section{Conclusion}

A new series of robust phosphite-oxazoline ligands has been successfully applied in the Pd-catalyzed enantioselective intermolecular Heck reaction. These ligands are based on one of the most successful phosphine-oxazoline ligand family $\mathbf{5}$ for this process, in which the phosphine moiety has been replaced by several biaryl phosphite groups. With these simple modifications, the phosphite-based ligands not only present, unlike 5, a modular design with numerous potential phosphite groups available, but they are also air-stable solids made in the same number of synthetic steps as the phosphine analogs. With a careful selection of the ligand components, (oxazoline substituent and its configuration, the substituents in the benzylic position and the substituents and configurations of the biaryl phosphite moiety) the new ligands were superior to the privileged phosphineoxazolines 5, extending the range of substrates and triflates sources than can be coupled with high regio-, enantioselectivities and activities. In addition, the phosphite-oxazoline ligands that provided the best selectivities contained the ${ }^{\mathrm{i}} \mathrm{Pr}$ substituent in the oxazoline moiety instead of the expensive ${ }^{t} \mathrm{Bu}$ substituent found in the related phosphine-oxazoline 5 . Interestingly, ligand L2a with the achiral biphenyl phosphite group provided activities and selectivities as high as those achieved using ligands containing chiral biaryl phosphite moieties. Studies of the coordination chemistry of the Pd-aryl intermediates have shown that the chirality of the oxazoline ligand backbone is able to control the tropoisomerism of the achiral biphenyl phosphite moiety in L2a, thus making the use of chiral phosphites superfluous. Preliminary kinetic studies in a practical regime indicated that migratory insertion of the alkene is rate-limiting and that most likely the more favourable formation of alkene adducts makes the phosphite based catalysts more active than the phosphine based ones.

\section{Experimental Section}

\section{General information}

All syntheses were performed with standard Schlenk techniques under argon atmosphere. The kinetic studies were performed using a glove box. Solvents were purified by standard procedures. All reagents were used as commercially available. Compounds 9-12, $,^{[16]} \mathbf{1 4},[17]$ phosphochloridites, ${ }^{[34]}$ ligands L1-L3a-e ${ }^{[15]}$ and $[\mathrm{Pd}(\mathrm{Ph})(\mathrm{I})(\mathrm{TMEDA})]^{[35]}$ were prepared as previously reported. ${ }^{1} \mathrm{H},{ }^{13} \mathrm{C}\left\{{ }^{1} \mathrm{H}\right\}$ and ${ }^{31} \mathrm{P}\left\{{ }^{1} \mathrm{H}\right\}$ NMR spectra were recorded on a Varian Gemini $400 \mathrm{MHz}$ spectrometer. The chemical shifts are referenced to tetramethylsilane $\left({ }^{1} \mathrm{H}\right.$ and ${ }^{13} \mathrm{C}$ ) as internal standard or $\mathrm{H}_{3} \mathrm{PO}_{4}\left({ }^{31} \mathrm{P}\right)$ as external standard. The ${ }^{1} \mathrm{H}$ and ${ }^{13} \mathrm{C}\left\{{ }^{1} \mathrm{H}\right\}$ NMR spectral assignments were determined by ${ }^{1} \mathrm{H}-{ }^{1} \mathrm{H}$ and ${ }^{1} \mathrm{H}-{ }^{13} \mathrm{C}$ correlation spectra.

\section{General procedure for the preparation of phosphite-oxazoline ligands}

To a solution of in situ generated phosphochloridite (1.1 $\mathrm{mmol})$ in dry toluene $(6 \mathrm{~mL})$, pyridine $(0.16 \mathrm{~mL}, 2.0 \mathrm{mmol})$ was added. Then, this solution was placed in a $-78^{\circ} \mathrm{C}$ bath. 
After $2 \mathrm{~min}$ at that temperature, a solution of the corresponding alcohol-oxazoline $(1.0 \mathrm{mmol})$ and pyridine $(0.16 \mathrm{~mL}, 2.0 \mathrm{mmol})$ in toluene $(6 \mathrm{~mL})$ was added drop wise at $-78^{\circ} \mathrm{C}$. The mixture was left to warm to room temperature and stirred overnight at this temperature. The precipitate formed was filtered under argon and the solvent was evaporated under vacuum. The residue was purified by flash chromatography (under argon, using neutral alumina and dry toluene as eluent system) to afford the corresponding phosphite-oxazoline as white solids.

(S)-4-Phenyl-2-(2-(2-((2,4,8,10-tetra-tertbutyldibenzo[d,f] $[1,3,2]$ dioxaphosphepin-6-

yl)oxy)phenyl)propan-2-yl)-4,5-dihydrooxazole (L4a): Yield: $261.5 \mathrm{mg}(40 \%) ;{ }^{3} \mathrm{P}$ NMR (161.9 MHz, $\left.\mathrm{C}_{6} \mathrm{D}_{6}\right): \delta=$ $137.0 \mathrm{ppm}(\mathrm{s}){ }^{\mathrm{P}} \mathrm{H}$ NMR $\left(400 \mathrm{MHz}^{\mathrm{C}} \mathrm{C}_{6} \mathrm{D}_{6}\right): \delta=1.22(\mathrm{~s}, 9 \mathrm{H}$, $\left.\mathrm{CH}_{3},{ }^{t} \mathrm{Bu}\right), 1.24\left(\mathrm{~s}, 9 \mathrm{H}, \mathrm{CH}_{3},{ }^{t} \mathrm{Bu}\right), 1.42\left(\mathrm{~s}, 9 \mathrm{H}, \mathrm{CH}_{3},{ }^{t} \mathrm{Bu}\right)$, $1.45\left(\mathrm{~s}, 9 \mathrm{H}, \mathrm{CH}_{3},{ }^{\circ} \mathrm{Bu}\right), 1.78\left(\mathrm{~s}, 3 \mathrm{H}, \mathrm{CH}_{3}\right), 1.80\left(\mathrm{~s}, 3 \mathrm{H}, \mathrm{CH}_{3}\right)$, $3.71\left(\mathrm{~m}, 1 \mathrm{H}, \mathrm{CH}_{2}-\mathrm{O}\right), 3.98$ (dd, $1 \mathrm{H}, \mathrm{CH}_{2}-\mathrm{O},{ }^{2} J_{\mathrm{H}-\mathrm{H}}=10.0 \mathrm{~Hz}$, $\left.{ }^{3} J_{\mathrm{H}-\mathrm{H}}=7.6 \mathrm{~Hz}\right), 4.92\left(\mathrm{dd}, 1 \mathrm{H}, \mathrm{CH}-\mathrm{N},{ }^{3} J_{\mathrm{H}-\mathrm{H}}=9.6 \mathrm{~Hz},{ }^{3} J_{\mathrm{H}-\mathrm{H}}=\right.$ $7.6 \mathrm{~Hz}), 6.83(\mathrm{~m}, 1 \mathrm{H}, \mathrm{CH}=), 6.90(\mathrm{~m}, 1 \mathrm{H}, \mathrm{CH}=), 7.01(\mathrm{~m}$, $2 \mathrm{H}, \mathrm{CH}=), 7.09(\mathrm{~m}, 3 \mathrm{H}, \mathrm{CH}=), 7.21(\mathrm{~s}, 1 \mathrm{H}, \mathrm{CH}=), 7.23(\mathrm{~s}$, $1 \mathrm{H}, \mathrm{CH}=), 7.03\left(\mathrm{~d}, 1 \mathrm{H},{ }^{3} J_{\mathrm{H}-\mathrm{H}}=2.0 \mathrm{~Hz}\right), 7.35\left(\mathrm{~d}, 1 \mathrm{H},{ }^{3} \mathrm{~J}_{\mathrm{H}-\mathrm{H}}=\right.$ $2.4 \mathrm{~Hz}), 7.54(\mathrm{~m}, 2 \mathrm{H}, \mathrm{CH}=) .{ }^{13} \mathrm{C}\left(100.6 \mathrm{MHz}, \mathrm{C}_{6} \mathrm{D}_{6}\right): \delta=$ $27.0\left(\mathrm{CH}_{3}\right), 27.9\left(\mathrm{CH}_{3}\right), 30.9\left(\mathrm{CH}_{3},{ }^{t} \mathrm{Bu}\right), 31.2\left(\mathrm{CH}_{3},{ }^{t} \mathrm{Bu}\right)$, $34.3\left(\mathrm{C},{ }^{t} \mathrm{Bu}\right), 35.3\left(\mathrm{C},{ }^{t} \mathrm{Bu}\right), 35.4\left(\mathrm{C},{ }^{t} \mathrm{Bu}\right), 39.7\left(\mathrm{C}, \mathrm{CMe}_{2}\right)$, 69.6 (CH-N), 74.5 (CH2-O), 120.6-150.3 (aromatic carbons), $173.1(\mathrm{C}=\mathrm{N})$.

\section{$(4 S)-2-(2-(2-(((11 b R)-2,6-$}

Bis(trimethylsilyl)dinaphtho[2,1-d:1',2'-

f] $[1,3,2]$ dioxaphosphepin-4-yl)oxy)phenyl)propan-2-yl)4-phenyl-4,5-dihydrooxazole (L4b). Yield: $261.5 \mathrm{mg}$ (40\%); ${ }^{31} \mathrm{P}$ NMR $\left(161.9 \mathrm{MHz}, \mathrm{C}_{6} \mathrm{D}_{6}\right): \dot{\delta}=142.1 \mathrm{ppm}(\mathrm{s}) .{ }^{1} \mathrm{H}$ NMR (400 MHz, $\left.\mathrm{C}_{6} \mathrm{D}_{6}\right): \delta=0.37\left(\mathrm{~s}, 9 \mathrm{H}, \mathrm{CH}_{3}-\mathrm{Si}\right), 0.41(\mathrm{~s}$, $\left.9 \mathrm{H}, \mathrm{CH}_{3}-\mathrm{Si}\right), 1.61\left(\mathrm{~s}, 3 \mathrm{H}, \mathrm{CH}_{3}\right), 1.67\left(\mathrm{~s}, 3 \mathrm{H}, \mathrm{CH}_{3}\right), 3.51(\mathrm{t}$, $\left.1 \mathrm{H}, \mathrm{CH} 2-\mathrm{O},{ }^{3} J_{\mathrm{H}-\mathrm{H}}={ }^{2} J_{\mathrm{H}-\mathrm{H}}=10.0 \mathrm{~Hz}\right), 3.86\left(\mathrm{dd}, 1 \mathrm{H}, \mathrm{CH}_{2}-\mathrm{O}\right.$, $\left.{ }^{2} J_{\mathrm{H}-\mathrm{H}}=10.0 \mathrm{~Hz},{ }^{3} J_{\mathrm{H}-\mathrm{H}}=8.0 \mathrm{~Hz}\right), 4.60\left(\mathrm{dd}, 1 \mathrm{H}, \mathrm{CH}-\mathrm{N},{ }^{3} J_{\mathrm{H}-\mathrm{H}}\right.$ $\left.=10.0 \mathrm{~Hz},{ }^{3} J_{\mathrm{H}-\mathrm{H}}=8.0 \mathrm{~Hz}\right), 6.79(\mathrm{~m}, 4 \mathrm{H}, \mathrm{CH}=), 6.96(\mathrm{~m}, 2 \mathrm{H}$, $\mathrm{CH}=), 7.07(\mathrm{~m}, 4 \mathrm{H}, \mathrm{CH}=), 7.24(\mathrm{~m}, 4 \mathrm{H}, \mathrm{CH}=), 7.65(\mathrm{~m}, 3 \mathrm{H}$, $\mathrm{CH}=), 8.07(\mathrm{~s}, 1 \mathrm{H}, \mathrm{CH}=), 8.14(\mathrm{~s}, 1 \mathrm{H}, \mathrm{CH}=) .{ }^{13} \mathrm{C}(100.6$ $\left.\mathrm{MHz}, \mathrm{C}_{6} \mathrm{D}_{6}\right): \delta=-0.2\left(\mathrm{~d}, \mathrm{CH}_{3}-\mathrm{Si}, J_{\mathrm{C}-\mathrm{P}}=4.5 \mathrm{~Hz}\right), 0.0\left(\mathrm{CH}_{3}-\right.$ $\mathrm{Si}), 27.0\left(\mathrm{CH}_{3}\right), 27.9\left(\mathrm{CH}_{3}\right), 40.0\left(\mathrm{C}, \mathrm{CMe}_{2}\right), 69.0(\mathrm{CH}-\mathrm{N})$, $74.1\left(\mathrm{CH}_{2}-\mathrm{O}\right), 119.6-152.4$ (aromatic carbons), 172.8 $(\mathrm{C}=\mathrm{N})$.

\section{$(4 S)-2-(2-(2-(((11 b S)-2,6-$}

Bis(trimethylsilyl)dinaphtho[2,1-d:1',2'-

f] $[1,3,2]$ dioxaphosphepin-4-yl)oxy)phenyl)propan-2-yl)4-phenyl-4,5-dihydrooxazole (L4c). Yield: $261.5 \mathrm{mg}$ (40\%); ${ }^{31} \mathrm{P}$ NMR (161.9 MHz, $\left.\mathrm{C}_{6} \mathrm{D}_{6}\right): \delta=142.3 \mathrm{ppm}(\mathrm{s}) .{ }^{1} \mathrm{H}$ NMR (400 MHz, $\left.\mathrm{C}_{6} \mathrm{D}_{6}\right): \delta=0.38\left(\mathrm{~s}, 9 \mathrm{H}, \mathrm{CH}_{3}-\mathrm{Si}\right), 0.40(\mathrm{~s}$, $\left.9 \mathrm{H}, \mathrm{CH}_{3}-\mathrm{Si}\right), 1.62\left(\mathrm{~s}, 3 \mathrm{H}, \mathrm{CH}_{3}\right), 1.76\left(\mathrm{~s}, 3 \mathrm{H}, \mathrm{CH}_{3}\right), 3.48(\mathrm{~m}$, $1 \mathrm{H}, \mathrm{CH}_{2}-\mathrm{O}$ ), 3.68 (dd, $1 \mathrm{H}, \mathrm{CH}_{2}-\mathrm{O},{ }^{2} J_{\mathrm{H}-\mathrm{H}}=10.4 \mathrm{~Hz},{ }^{3} J_{\mathrm{H}-\mathrm{H}}=$ $8.0 \mathrm{~Hz}), 4.25\left(\mathrm{dd}, 1 \mathrm{H}, \mathrm{CH}-\mathrm{N},{ }^{3} J_{\mathrm{H}-\mathrm{H}}=10.0 \mathrm{~Hz},{ }^{3} J_{\mathrm{H}-\mathrm{H}}=8.0\right.$ $\mathrm{Hz}), 6.80(\mathrm{~m}, 5 \mathrm{H}, \mathrm{CH}=), 6.88(\mathrm{~m}, 1 \mathrm{H}, \mathrm{CH}=), 6.9-7.1(\mathrm{~m}, 5 \mathrm{H}$, $\mathrm{CH}=), 7.23(\mathrm{~m}, 4 \mathrm{H}, \mathrm{CH}=), 7.63(\mathrm{~m}, 1 \mathrm{H}, \mathrm{CH}=), 7.66(\mathrm{~m}, 1 \mathrm{H}$, $\mathrm{CH}=), 8.08(\mathrm{~s}, 1 \mathrm{H}, \mathrm{CH}=), 8.09(\mathrm{~s}, 1 \mathrm{H}, \mathrm{CH}=) .{ }^{13} \mathrm{C}(100.6$ $\left.\mathrm{MHz}, \mathrm{C}_{6} \mathrm{D}_{6}\right): \delta=-0.2\left(\mathrm{~d}, \mathrm{CH}_{3}-\mathrm{Si}, J_{\mathrm{C}-\mathrm{P}}=4.5 \mathrm{~Hz}\right), 0.0\left(\mathrm{CH}_{3}-\right.$ $\mathrm{Si}), 26.8\left(\mathrm{CH}_{3}\right), 28.4\left(\mathrm{CH}_{3}\right), 39.7\left(\mathrm{C}, \mathrm{CMe}_{2}\right), 69.0(\mathrm{CH}-\mathrm{N})$, $74.4\left(\mathrm{CH}_{2}-\mathrm{O}\right), 119.9-152.3$ (aromatic carbons), 172.5 $(\mathrm{C}=\mathrm{N})$.

\section{Synthesis of (S)-2-(2-(4-phenyl-4,5-dihydrooxazol-2-yl)propan- 2-yl)phenol (15)}

$\mathrm{MeOH}(7.21 \mathrm{ml}, 0.29 \mathrm{mmol})$ was added to a solution of $\mathrm{NaH}$ (60\% in mineral oil, $244.16 \mathrm{mg}, 6.10 \mathrm{mmol})$ in THF $(5.1 \mathrm{ml})$ at $0^{\circ} \mathrm{C}$ under argon and string for $1 \mathrm{~h}$. The solution of 3,3dimethylbenzofuran-2(3H)-one $14(700 \mathrm{mg}, 5.55 \mathrm{mmol})$ in THF $(5.1 \mathrm{ml})$ was added at $0{ }^{\circ} \mathrm{C}$. The resultant mixture was warmed to room temperature during $1 \mathrm{~h}$. A solution of $(S)$ (+)-2-phenylglycinol $(837.34 \mathrm{mg}, 6.10 \mathrm{mmol})$ in THF $(5.1$ $\mathrm{ml})$ was added dropwise. The mixture was stirred for $2 \mathrm{~h}$. The mixture was suspended in $\mathrm{CH}_{2} \mathrm{Cl}_{2}(30 \mathrm{~mL})$ and washed with $\mathrm{NaOH}$ solution $(2 \times 50 \mathrm{~mL})$, then with $2 \mathrm{M} \mathrm{HCl}$ solution to reach to $\mathrm{pH}=2$. After drying over $\mathrm{MgSO}_{4}$, solvent was evaporated to obtain intermediate $(S)-\mathrm{N}-(2-$ hydroxy-1-phenylethyl)-2-(2-hydroxyphenyl)-2-

methylpropanamide as a white solid. Yield: $1.17 \mathrm{~g}(75 \%)$ ${ }^{1} \mathrm{H}$ NMR (400 MHz, $\left.\mathrm{C}_{6} \mathrm{D}_{6}\right): \delta=1.59\left(\mathrm{~s}, 3 \mathrm{H}, \mathrm{CH}_{3}\right), 1.63(\mathrm{~s}$, $\left.3 \mathrm{H}, \mathrm{CH}_{3}\right), 3.72\left(\mathrm{dd}, 1 \mathrm{H}, \mathrm{CH}_{2}-\mathrm{O},{ }^{2} J_{\mathrm{H}-\mathrm{H}}=11.4 \mathrm{~Hz},{ }^{3} J_{\mathrm{H}-\mathrm{H}}=7.2\right.$ $\mathrm{Hz}), 3.90\left(\mathrm{dd}, 1 \mathrm{H}, \mathrm{CH}_{2}-\mathrm{O},{ }^{2} J_{\mathrm{H}-\mathrm{H}}=11.4 \mathrm{~Hz},{ }^{3} J_{\mathrm{H}-\mathrm{H}}=4.0 \mathrm{~Hz}\right.$ ), $5.11(\mathrm{~m}, 1 \mathrm{H}, \mathrm{CH}), 6.12\left(\mathrm{~d}, 1 \mathrm{H}, \mathrm{NH},{ }^{3} \mathrm{~J}_{\mathrm{H}-\mathrm{H}}=7.6 \mathrm{~Hz}\right), 6.92$ $(\mathrm{m}, 2 \mathrm{H}, \mathrm{CH}=), 7.18(\mathrm{~m}, 3 \mathrm{H}, \mathrm{CH}=), 7.29(\mathrm{~m}, 4 \mathrm{H}, \mathrm{CH}=) \cdot{ }^{13} \mathrm{C}$ $\left(100.6 \mathrm{MHz}, \mathrm{C}_{6} \mathrm{D}_{6}\right): \delta=25.2\left(\mathrm{CH}_{3}\right), 25.9\left(\mathrm{CH}_{3}\right), 45.3(\mathrm{C}$, $\left.\mathrm{CMe}_{2}\right), 55.6(\mathrm{CH}-\mathrm{N}), 66.05\left(\mathrm{CH}_{2}-\mathrm{O}\right), 117-155$ (aromatic carbons).

To a cold $\left(0{ }^{\circ} \mathrm{C}\right)$ solution of $(S)-N$-(2-hydroxy-1phenylethyl)-2-(2-hydroxyphenyl)-2-methylpropanamide $(1.25 \mathrm{~g}, 4.18 \mathrm{mmol})$ in $\mathrm{CH}_{2} \mathrm{Cl}_{2}(10 \mathrm{~mL})$ was sequentially added triethylamine $(2.91 \mathrm{~mL}, 20.88 \mathrm{mmol})$, DMAP (76 $\mathrm{mg}, 0.63 \mathrm{mmol})$ and methanesulfonyl chloride $(0.36 \mathrm{~mL}$, $4.59 \mathrm{mmol})$. The resultant mixture was warmed to room temperature and stirred overnight. The excess methanesulfonyl chloride was hydrolyzed by adding water $(10 \mathrm{~mL})$ and heating to reflux for $30 \mathrm{~min}$. Another portion of water $(25 \mathrm{~mL})$ was added, and the mixture was extracted with $\mathrm{CH}_{2} \mathrm{Cl}_{2}(3 \times 25 \mathrm{~mL})$. The combined organic phases were washed with saturated $\mathrm{NaCl}$ solution and dried over $\mathrm{Na}_{2} \mathrm{SO}_{4}$. After filtration and removal of the solvent under vacuum, the product was purified by flash chromatography, $5 \%$ methanol in dichloromethane. Yield: $705 \mathrm{mg}(60 \%) .{ }^{1} \mathrm{H}$ NMR (400 MHz, C6 6 ) : $\delta=1.69\left(\mathrm{~b}, 6 \mathrm{H}, \mathrm{CH}_{3}\right), 4.08(\mathrm{~b}, 1 \mathrm{H}$, $\left.\mathrm{CH}_{2}\right), 4.63(\mathrm{~b}, 1 \mathrm{H}, \mathrm{CH}), 4.5 .17\left(\mathrm{~b}, 1 \mathrm{H}, \mathrm{CH}_{2}\right), 6.8-7.4(\mathrm{~m}, 9 \mathrm{H}$, $\mathrm{CH}=$ ). MS HR-ESI [found 281.1416, $\mathrm{C}_{18} \mathrm{H}_{19} \mathrm{NO}_{2}$ requires 281.1417].

\section{General procedure for the synthesis of $[P d(I)(P h)(L)]$ complexes 16-19}

A solution of $[\mathrm{Ph}(\mathrm{I})(\mathrm{Ph})(\mathrm{TMEDA})](25 \mathrm{mg}, 0.058 \mathrm{mmol})$ and the corresponding ligand $(0.058 \mathrm{mmol})$ in dry degassed benzene $(3 \mathrm{ml})$ was stirred under Ar atmosphere at r.t. for $48 \mathrm{~h}$. The reaction was monitored by ${ }^{31} \mathrm{P}\left\{{ }^{1} \mathrm{H}\right\}$ NMR during this time. The organic solvent was removed under reduced pressure. Purification by column chromatography (neutral $\mathrm{Al}_{2} \mathrm{O}_{3}$; toluene $/ \mathrm{CH}_{2} \mathrm{Cl}_{2}$ gradient $1: 0$ to $0: 1$ ) yielded the desired products as pale-yellow solids.

\section{(Iodo) $[(S)-4$-isopropyl-2-(2-( $(2,4,8,10$-tetra-tert- \\ butyldibenzo $[d, f][1,3,2]$ dioxaphosphepin-6-} yl)oxy)benzyl)-4,5-dihydrooxazole (phenyl)palladium

[Pd(I)(Ph)(L2a)] (16). Yield: $37 \mathrm{mg}(66 \%)$. MS HR-ESI [found 840.3371, $\mathrm{C}_{47} \mathrm{H}_{61} \mathrm{NO}_{4} \mathrm{PPd}^{+}$requires 840.3368$] .{ }^{31} \mathrm{P}$ NMR (162 MHz, $\left.\mathrm{CD}_{2} \mathrm{Cl}_{2}\right) \delta$ 96.7. ${ }^{1} \mathrm{H}$ NMR $(400 \mathrm{MHz}$, $\left.\mathrm{C}_{6} \mathrm{D}_{6}\right), \delta: 7.56(\mathrm{~d}, 2 \mathrm{H}, J=2.3 \mathrm{~Hz}, \mathrm{CH}=), 7.46(\mathrm{~d}, 1 \mathrm{H}, J=$ $2.3 \mathrm{~Hz}, \mathrm{CH}=), 7.13\left(\mathrm{~d}, 1 \mathrm{H},{ }^{3} J_{\mathrm{H}-\mathrm{H}}=7.5 \mathrm{~Hz}, \mathrm{CH}=\right), 7.02(\mathrm{~d}$, $\left.1 \mathrm{H},{ }^{3} J_{\mathrm{H}-\mathrm{H}}=6.9 \mathrm{~Hz}, \mathrm{CH}=\right), 6.85-6.80(\mathrm{~m}, 4 \mathrm{H}, \mathrm{CH}=), 6.77-$ $6.68(\mathrm{~m}, 2 \mathrm{H}, \mathrm{CH}=), 6.63-6.54(\mathrm{~m}, 2 \mathrm{H}, \mathrm{CH}=), 5.94(\mathrm{~d}, 1 \mathrm{H}$, $\left.{ }^{3} J_{\mathrm{H}-\mathrm{H}}=7.3 \mathrm{~Hz}, \mathrm{CH}-\mathrm{N}\right), 4.67\left(\mathrm{~d}, 1 \mathrm{H},{ }^{2} J_{\mathrm{H}-\mathrm{H}}=14.5 \mathrm{~Hz}, \mathrm{CH}_{2}\right)$, $3.72-3.60(\mathrm{~m}, 2 \mathrm{H}, \mathrm{CH}-\mathrm{O}), 3.10\left(\mathrm{~d}, 1 \mathrm{H},{ }^{2} J_{\mathrm{H}-\mathrm{H}}=14.6 \mathrm{~Hz}\right.$, $\left.\mathrm{CH}_{2}\right), 2.94\left(\mathrm{~m}, 1 \mathrm{H}, \mathrm{CH},{ }^{i} \mathrm{Pr}\right), 1.58\left(\mathrm{~s}, 18 \mathrm{H}, \mathrm{CH}_{3},{ }^{t} \mathrm{Bu}\right), 1.19$ $\left(\mathrm{s}, 9 \mathrm{H}, \mathrm{CH}_{3},{ }^{t} \mathrm{Bu}\right), 1.13\left(\mathrm{~s}, 9 \mathrm{H}, \mathrm{CH}_{3},{ }^{t} \mathrm{Bu}\right), 0.97\left(\mathrm{~d}, 3 \mathrm{H},{ }^{3} J_{\mathrm{H}-}\right.$ $\left.{ }^{\mathrm{H}}=6.8 \mathrm{~Hz}, \mathrm{CH}_{3},{ }^{i} \mathrm{Pr}\right), 0.87\left(\mathrm{~d}, 3 \mathrm{H},{ }^{3} \mathrm{~J}_{\mathrm{H}-\mathrm{H}}=6.9 \mathrm{~Hz}, \mathrm{CH}_{3},{ }^{i} \mathrm{Pr}\right)$. ${ }^{13} \mathrm{C}$ NMR $\left(100 \mathrm{MHz}, \mathrm{C}_{6} \mathrm{D}_{6}\right), \delta: 166.3(\mathrm{C}=\mathrm{N}), 152.7\left(\mathrm{~d}, \mathrm{C}_{\mathrm{ipso}}\right.$, $\left.J_{\mathrm{C}-\mathrm{P}}=15.8 \mathrm{~Hz}\right), 148.4\left(\mathrm{~d}, \mathrm{C}-\mathrm{O}, J_{\mathrm{C}-\mathrm{P}}=16.1 \mathrm{~Hz}\right), 147.3$ (d, C$\left.\mathrm{O}, J_{\mathrm{C}-\mathrm{P}}=6.2 \mathrm{~Hz}\right), 148.445 .6\left(\mathrm{~d}, \mathrm{C}-\mathrm{O}, J_{\mathrm{C}-\mathrm{P}}=11.2 \mathrm{~Hz}\right), 138.7-$ 121.3 (aromatic carbons), 72.3 (CH-O), $69.8(\mathrm{CH}-\mathrm{N}), 36.2$ $\left(\mathrm{CH}_{2}\right), 34.6(\mathrm{C}), 31.7\left(\mathrm{CH}_{3},{ }^{t} \mathrm{Bu}\right), 31.5\left(\mathrm{CH}_{3},{ }^{t} \mathrm{Bu}\right), 31.4$ $\left(\mathrm{CH}_{3},{ }^{t} \mathrm{Bu}\right), 31.3\left(\mathrm{CH}_{3},{ }^{t} \mathrm{Bu}\right), 31.0\left(\mathrm{C},{ }^{i} \mathrm{Pr}\right), 19.3\left(\mathrm{CH}_{3},{ }^{i} \mathrm{Pr}\right)$, $16.2\left(\mathrm{CH}_{3},{ }^{i} \mathrm{Pr}\right)$.

\section{(Iodo)(phenyl) [(4S)-2-(2-(((11bR)-2,6-}

\section{bis(trimethylsilyl)dinaphtho[2,1-d:1',2'-}

f] $[1,3,2]$ dioxaphosphepin-4-yl)oxy)benzyl)-4-isopropyl4,5-dihydrooxazole]palladium [Pd(I)(Ph)(L2b)] (17). Yield: $6 \mathrm{mg}(12 \%)$. MS HR-ESI [found 860.1959, $\mathrm{C}_{45} \mathrm{H}_{49} \mathrm{NO}_{4} \mathrm{PPdSi}_{2}{ }^{+}$requires 860.1967$]$. Major isomer: ${ }^{31} \mathrm{P}$ NMR $\left(162 \mathrm{MHz}, \mathrm{CD}_{2} \mathrm{Cl}_{2}\right) \delta 112.3(\mathrm{~b}, 1 \mathrm{P}) .{ }^{1} \mathrm{H}$ NMR (400 $\left.\mathrm{MHz}, \mathrm{CD}_{2} \mathrm{Cl}_{2}\right), \delta: 0.62\left(\mathrm{~s}, 18 \mathrm{H}, \mathrm{SiMe}_{3}\right), 0.96\left(\mathrm{~d}, 6 \mathrm{H},{ }^{3} J_{\mathrm{H}-\mathrm{H}}=\right.$ $\left.5.6 \mathrm{~Hz}, \mathrm{CH}_{3},{ }^{\mathrm{P}} \mathrm{r}\right), 2.61\left(\mathrm{~m}, 1 \mathrm{H}, \mathrm{CH},{ }^{\mathrm{i}} \mathrm{Pr}\right), 4.27\left(\mathrm{~m}, 1 \mathrm{H}, \mathrm{CH}_{2}\right)$, $4.30\left(\mathrm{~m}, 2 \mathrm{H}, \mathrm{CH}_{2}-\mathrm{O}\right), 4.40\left(\mathrm{~m}, 1 \mathrm{H}, \mathrm{CH}_{2}\right), 4.70(\mathrm{~m}, 1 \mathrm{H}, \mathrm{CH}-$ $\mathrm{N}), 6.10(\mathrm{~m}, 1 \mathrm{H}, \mathrm{CH}=), 6.7-7.9(\mathrm{~m}, 17 \mathrm{H}, \mathrm{CH}=), 8.20(\mathrm{~s}, 1 \mathrm{H}$, $\mathrm{CH}=)$. Minor isomer: ${ }^{31} \mathrm{P}$ NMR $\left(162 \mathrm{MHz}, \mathrm{CD}_{2} \mathrm{Cl}_{2}\right) \delta 104.6$ 
(b, 1P). ${ }^{1} \mathrm{H}$ NMR (400 MHz, $\left.\mathrm{CD}_{2} \mathrm{Cl}_{2}\right), \delta: 0.45(\mathrm{~s}, 18 \mathrm{H}$, $\left.\mathrm{SiMe}_{3}\right), 0.91\left(\mathrm{~d}, 3 \mathrm{H},{ }^{3} \mathrm{~J}_{\mathrm{H}-\mathrm{H}}=5.6 \mathrm{~Hz}, \mathrm{CH}_{3},{ }^{\mathrm{P}} \mathrm{Pr}\right), 0.93(\mathrm{~d}, 3 \mathrm{H}$, $\left.{ }^{3} J_{\mathrm{H}-\mathrm{H}}=5.6 \mathrm{~Hz}, \mathrm{CH}_{3},{ }^{,} \mathrm{Pr}\right), 2.61\left(\mathrm{~m}, 1 \mathrm{H}, \mathrm{CH},{ }^{\mathrm{i}} \mathrm{Pr}\right), 4.24(\mathrm{~m}, 1 \mathrm{H}$, $\left.\mathrm{CH}_{2}\right), 4.31\left(\mathrm{~m}, 2 \mathrm{H}, \mathrm{CH}_{2}-\mathrm{O}\right), 4.40\left(\mathrm{~m}, 1 \mathrm{H}, \mathrm{CH}_{2}\right), 4.73(\mathrm{~m}$, $1 \mathrm{H}, \mathrm{CH}-\mathrm{N}), 5.94(\mathrm{~m}, 1 \mathrm{H}, \mathrm{CH}=), 6.7-7.9(\mathrm{~m}, 17 \mathrm{H}, \mathrm{CH}=)$, $8.25(\mathrm{~s}, 1 \mathrm{H}, \mathrm{CH}=)$.

\section{(Iodo)(phenyl) [(4S)-2-(2-(((11bS)-2,6-}

bis(trimethylsilyl)dinaphtho[2,1-d:1',2'-

f] [1,3,2]dioxaphosphepin-4-yl)oxy)benzyl)-4-isopropyl4,5-dihydrooxazolelpalladium [Pd(I)(Ph)(L2c)] (18). Yield: $36 \mathrm{mg}(73 \%)$. MS HR-ESI ffound 860.1961, $\mathrm{C}_{45} \mathrm{H}_{49} \mathrm{NO}_{4} \mathrm{PPdSi}_{2}{ }^{+}$requires 860.1967 . Major isomer: ${ }^{31} \mathrm{P}$ NMR (162 MHz, $\left.\mathrm{CD}_{2} \mathrm{Cl}_{2}\right) \delta 101.2 .{ }^{1} \mathrm{H}$ NMR $(400 \mathrm{MHz}$, $\mathrm{CD}_{2} \mathrm{Cl}_{2}$ ), $\delta: 0.62$ (s, 9H, SiMe $), 0.65$ (s, 9H, SiMe $), 1.02$ $\left(\mathrm{d}, 3 \mathrm{H},{ }^{3} J_{\mathrm{H}-\mathrm{H}}=5.8 \mathrm{~Hz}, \mathrm{CH}_{3},{ }^{\mathrm{i}} \mathrm{Pr}\right), 1.10\left(\mathrm{~d}, 3 \mathrm{H},{ }^{3} \mathrm{~J}_{\mathrm{H}-\mathrm{H}}=5.6 \mathrm{~Hz}\right.$, $\left.\mathrm{CH}_{3},{ }^{\mathrm{i}} \mathrm{Pr}\right), 2.74\left(\mathrm{~m}, 1 \mathrm{H}, \mathrm{CH},{ }^{1} \mathrm{Pr}\right), 3.57\left(\mathrm{~d}, 1 \mathrm{H},{ }^{2} J_{\mathrm{H}-\mathrm{H}}=11.0 \mathrm{~Hz}\right.$, $\left.\mathrm{CH}_{2}\right), 4.27\left(\mathrm{~m}, 1 \mathrm{H}, \mathrm{CH}_{2}-\mathrm{O}\right), 4.41\left(\mathrm{dd}, 1 \mathrm{H},{ }^{2} J_{\mathrm{H}-\mathrm{H}}=8.4 \mathrm{~Hz},{ }^{3} J_{\mathrm{H}-}\right.$ $\left.\mathrm{H}=7.2 \mathrm{~Hz}, \mathrm{CH}_{2}-\mathrm{O}\right), 4.60\left(\mathrm{~d}, 1 \mathrm{H},{ }^{2} J_{\mathrm{H}-\mathrm{H}}=11.0 \mathrm{~Hz}, \mathrm{CH}_{2}\right), 5.15$ $(\mathrm{m}, 1 \mathrm{H}, \mathrm{CH}-\mathrm{N}), 5.84\left(\mathrm{~d}, 1 \mathrm{H},{ }^{3} J_{\mathrm{H}-\mathrm{H}}=6.6 \mathrm{~Hz}, \mathrm{CH}=\right), 5.97(\mathrm{~m}$, $1 \mathrm{H}, \mathrm{CH}=), 6.26(\mathrm{~m}, 1 \mathrm{H}, \mathrm{CH}=), 6.71(\mathrm{~m}, 2 \mathrm{H}, \mathrm{CH}=), 6.84(\mathrm{~m}$, $1 \mathrm{H}, \mathrm{CH}=), 7.03(\mathrm{~m}, 1 \mathrm{H}, \mathrm{CH}=), 7.12(\mathrm{~m}, 3 \mathrm{H}, \mathrm{CH}=), 7.26(\mathrm{~m}$, $1 \mathrm{H}, \mathrm{CH}=), 7.44(\mathrm{~m}, 3 \mathrm{H}, \mathrm{CH}=), 7.95(\mathrm{~m}, 3 \mathrm{H}, \mathrm{CH}=), 8.14(\mathrm{~s}$, $1 \mathrm{H}, \mathrm{CH}=), 8.25 \mathrm{~s}, 1 \mathrm{H}, \mathrm{CH}=) .{ }^{13} \mathrm{C}$ NMR $(100 \mathrm{MHz}$, $\left.\mathrm{CD}_{2} \mathrm{Cl}_{2}\right), \delta: 0.3\left(\mathrm{CH}_{3}-\mathrm{Si}\right), 0.46\left(\mathrm{CH}_{3}-\mathrm{Si}\right), 16.1\left(\mathrm{CH}_{3},{ }^{\mathrm{i}} \mathrm{Pr}\right)$, 19.6 $\left(\mathrm{CH}_{3},{ }^{\mathrm{i}} \mathrm{Pr}\right), 30.6\left(\mathrm{CH},{ }^{\mathrm{i}} \mathrm{Pr}\right), 34.7\left(\mathrm{CH}_{2}\right), 70.0\left(\mathrm{CH}_{2}-\mathrm{O}\right)$, $71.9(\mathrm{CH}-\mathrm{N}), 113.7-138.2$ (aromatic carbons), $150.3(\mathrm{~d}, \mathrm{C}-$ $\left.\mathrm{O}, J_{\mathrm{C}-\mathrm{P}}=11 \mathrm{~Hz}\right), 151.5\left(\mathrm{~d}, \mathrm{C}-\mathrm{O}, J_{\mathrm{C}-\mathrm{P}}=6.4 \mathrm{~Hz}\right), 151.6\left(\mathrm{~d}, \mathrm{C}_{\mathrm{ipso}}\right.$, $\left.J_{\mathrm{C}-\mathrm{P}}=18.6 \mathrm{~Hz}\right), 151.7\left(\mathrm{~d}, \mathrm{C}-\mathrm{O}, J_{\mathrm{C}-\mathrm{P}}=3.2 \mathrm{~Hz}\right), 166.5(\mathrm{~d}, \mathrm{C}=\mathrm{N}$, $\left.J_{\mathrm{C}-\mathrm{P}}=3.0 \mathrm{~Hz}\right)$. Minor isomer: ${ }^{31} \mathrm{P}$ NMR $\left(162 \mathrm{MHz}, \mathrm{CD}_{2} \mathrm{Cl}_{2}\right)$ $\delta$ 110.8. ${ }^{1} \mathrm{H}$ NMR $\left(400 \mathrm{MHz}, \mathrm{CD}_{2} \mathrm{Cl}_{2}\right), \delta: 0.63(\mathrm{~s}, 9 \mathrm{H}$, $\left.\mathrm{SiMe}_{3}\right), 0.66\left(\mathrm{~s}, 9 \mathrm{H}, \mathrm{SiMe}_{3}\right), 1.02\left(\mathrm{~d}, 3 \mathrm{H},{ }^{3} \mathrm{~J}_{\mathrm{H}-\mathrm{H}}=5.8 \mathrm{~Hz}, \mathrm{CH}_{3}\right.$ $\left.{ }^{\mathrm{i} P r}\right), 1.09\left(\mathrm{~d}, 3 \mathrm{H},{ }^{3} \mathrm{~J}_{\mathrm{H}-\mathrm{H}}=5.6 \mathrm{~Hz}, \mathrm{CH}_{3},{ }^{\mathrm{i}} \mathrm{Pr}\right), 2.74(\mathrm{~m}, 1 \mathrm{H}, \mathrm{CH}$, $\left.{ }^{i} \mathrm{Pr}\right), 3.59$ (d, $\left.1 \mathrm{H},{ }^{2} \mathrm{~J}_{\mathrm{H}-\mathrm{H}}=11.0 \mathrm{~Hz}, \mathrm{CH}_{2}\right), 4.27\left(\mathrm{~m}, 1 \mathrm{H}, \mathrm{CH}_{2}-\right.$ O), $4.46\left(\mathrm{dd}, 1 \mathrm{H},{ }^{2} J_{\mathrm{H}-\mathrm{H}}=8.2 \mathrm{~Hz},{ }^{3} \mathrm{~J}_{\mathrm{H}-\mathrm{H}}=7.2 \mathrm{~Hz}, \mathrm{CH}_{2}-\mathrm{O}\right), 4.61$ $\left(\mathrm{d}, 1 \mathrm{H},{ }^{2} J_{\mathrm{H}-\mathrm{H}}=11.4 \mathrm{~Hz}, \mathrm{CH}_{2}\right), 4.95(\mathrm{~m}, 1 \mathrm{H}, \mathrm{CH}-\mathrm{N}), 5.80(\mathrm{~d}$, $\left.1 \mathrm{H},{ }^{3} J_{\mathrm{H}-\mathrm{H}}=6.6 \mathrm{~Hz}, \mathrm{CH}=\right), 6.13(\mathrm{~m}, 1 \mathrm{H}, \mathrm{CH}=), 6.71(\mathrm{~m}, 2 \mathrm{H}$, $\mathrm{CH}=), 6.84(\mathrm{~m}, 1 \mathrm{H}, \mathrm{CH}=), 6.90(\mathrm{~m}, 1 \mathrm{H}, \mathrm{CH}=), 7.03(\mathrm{~m}, 1 \mathrm{H}$, $\mathrm{CH}=), 7.12(\mathrm{~m}, 3 \mathrm{H}, \mathrm{CH}=), 7.26(\mathrm{~m}, 1 \mathrm{H}, \mathrm{CH}=), 7.44(\mathrm{~m}, 3 \mathrm{H}$, $\mathrm{CH}=), 7.95(\mathrm{~m}, 3 \mathrm{H}, \mathrm{CH}=), 8.11(\mathrm{~s}, 1 \mathrm{H}, \mathrm{CH}=), 8.26(\mathrm{~s}, 1 \mathrm{H}$, $\mathrm{CH}=) .{ }^{13} \mathrm{C}$ NMR (100 MHz, $\left.\mathrm{CD}_{2} \mathrm{Cl}_{2}\right), \delta: 0.2\left(\mathrm{CH}_{3}-\mathrm{Si}\right), 0.3$ $\left(\mathrm{CH}_{3}-\mathrm{Si}\right), 16.1\left(\mathrm{CH}_{3},{ }^{\mathrm{i}} \mathrm{Pr}\right), 19.5\left(\mathrm{CH}_{3},{ }^{\mathrm{i}} \mathrm{Pr}\right), 30.7\left(\mathrm{CH},{ }^{i} \mathrm{Pr}\right)$, $34.7\left(\mathrm{CH}_{2}\right), 69.4(\mathrm{CH}-\mathrm{N}), 69.9\left(\mathrm{CH}_{2}-\mathrm{O}\right), 113.7-138.2$ (aromatic carbons), 150.4 (d, C-O, $\left.J_{\mathrm{C}-\mathrm{P}}=10 \mathrm{~Hz}\right), 151.4(\mathrm{~d}$, $\mathrm{C}-\mathrm{O}, J_{\mathrm{C}-\mathrm{P}}=6.4 \mathrm{~Hz}$ ), 151.7 (d, C-O, $\left.J_{\mathrm{C}-\mathrm{P}}=3.0 \mathrm{~Hz}\right), 166.4$ (d, $\mathrm{C}=\mathrm{N}, J_{\mathrm{C}-\mathrm{P}}=2.6 \mathrm{~Hz}$ ).

[(4S)-2-(2-(((11aS)-4,8-di-tert-butyl-1,2,10,11tetramethyldibenzo[d,f] [1,3,2] dioxaphosphepin-6yl)oxy)benzyl)-4-isopropyl-4,5-

dihydrooxazole](iodo)(phenyl)palladium

[Pd(I)(Ph)(L2e)] (19). Yield: $32 \mathrm{mg}$ (71\%). MS HR-ESI found $784.2739, \mathrm{C}_{43} \mathrm{H}_{53} \mathrm{NO}_{4} \mathrm{PPd}^{+}$requires 784.2742 ]. ${ }^{31} \mathrm{P}$ NMR (162 MHz, $\left.\mathrm{CD}_{2} \mathrm{Cl}_{2}\right) \delta 91.3$ (s). ${ }^{1} \mathrm{H}$ NMR $(400 \mathrm{MHz}$, $\left.\mathrm{CD}_{2} \mathrm{Cl}_{2}\right), \delta: 0.99\left(\mathrm{~s}, 6 \mathrm{H}, \mathrm{CH}_{3},{ }^{\mathrm{i}} \mathrm{Pr}\right), 1.50\left(\mathrm{~s}, 9 \mathrm{H}, \mathrm{CH}_{3},{ }^{\mathrm{t}} \mathrm{Bu}\right)$, $1.56\left(\mathrm{~s}, 9 \mathrm{H}, \mathrm{CH}_{3},{ }^{\mathrm{t}} \mathrm{Bu}\right), 2.20\left(\mathrm{~s}, 3 \mathrm{H}, \mathrm{CH}_{3}\right), 2.23\left(\mathrm{~s}, 6 \mathrm{H}, \mathrm{CH}_{3}\right)$ $2.30\left(\mathrm{~s}, 3 \mathrm{H}, \mathrm{CH}_{3}\right), 2.73(\mathrm{~m}, 1 \mathrm{H}, \mathrm{CH}, \mathrm{Pr}), 3.53\left(\mathrm{~d}, 1 \mathrm{H},{ }^{2} J_{\mathrm{H}-\mathrm{H}}=\right.$ $\left.14.0 \mathrm{~Hz} \mathrm{CH}_{2}\right), 4.22\left(\mathrm{~m}, 1 \mathrm{H}, \mathrm{CH}_{2}-\mathrm{O}\right), 4.34\left(\mathrm{~m}, 1 \mathrm{H}, \mathrm{CH}_{2}-\mathrm{O}\right)$, $4.56\left(\mathrm{~d}, 1 \mathrm{H},{ }^{2} J_{\mathrm{H}-\mathrm{H}}=14.0 \mathrm{~Hz}, \mathrm{CH}_{2}\right), 5.05(\mathrm{~m}, 1 \mathrm{H}, \mathrm{CH}-\mathrm{N}), 5.84$ $\left(\mathrm{d}, 1 \mathrm{H},{ }^{3} J_{\mathrm{H}-\mathrm{H}}=7.6 \mathrm{~Hz}, \mathrm{CH}=\right), 6.51(\mathrm{~m}, 2 \mathrm{H}, \mathrm{CH}=), 6.7-7.3(\mathrm{~m}$, $7 \mathrm{H}, \mathrm{CH}=), 7.35(\mathrm{~s}, 1 \mathrm{H}, \mathrm{CH}=) .{ }^{13} \mathrm{C}$ NMR $(100 \mathrm{MHz}$, $\left.\mathrm{CD}_{2} \mathrm{Cl}_{2}\right), \delta: 15.6\left(\mathrm{CH}_{3},{ }^{1} \mathrm{Pr}\right), 15.7\left(\mathrm{CH}_{3},{ }^{\mathrm{i}} \mathrm{Pr}\right), 19.1\left(\mathrm{CH}_{3}\right), 19.7$

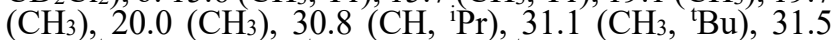
$\left(\mathrm{CH}_{3},{ }^{\mathrm{t}} \mathrm{Bu}\right), 34.1$ (C, $\left.{ }^{\mathrm{t}} \mathrm{Bu}\right), 34.3\left(\mathrm{C},{ }^{\mathrm{t}} \mathrm{Bu}\right), 34.7\left(\mathrm{CH}_{2}\right), 69.7$ $\left(\mathrm{CH}_{2}-\mathrm{O}\right), 71.9(\mathrm{CH}-\mathrm{N}), 121.0-143.7$ (aromatic carbons), $145.3\left(\mathrm{~d}, \mathrm{C}_{\mathrm{ipso}}, J_{\mathrm{C}-\mathrm{P}}=16.4 \mathrm{~Hz}\right), 166.5(\mathrm{C}=\mathrm{N})$.

Synthesis of (iodo) [(S)-4-isopropyl-2-(2-((2,4,8,10-tetra-tertbutyldibenzo[d,f][1,3,2]dioxaphosphepin-6-yl)oxy)benzyl)-4,5dihydrooxazole](trifluoromethanesulphonate)palladium [Pd(Ph)(OTf)(L2a)] (26)

Silver triflate $(16 \mathrm{mg}, 0.062 \mathrm{mmol})$ was added to a vigorously stirred solution of the complex $[\mathrm{Pd}(\mathrm{I})(\mathrm{Ph})(\mathbf{L} 2 \mathbf{2 a})]$ $(30 \mathrm{mg}, 0.031 \mathrm{mmol})$ in dry degassed THF (4 ml) under Ar atmosphere at r.t.. Stirring was continued for $1 \mathrm{~h}$, during which period a pale grey precipitate was formed. The reaction mixture then filtered over celite, and all volatiles were removed under reduced pressure to yield the final product as a pale brown solid (55 mg, $90 \%)$. ${ }^{31} \mathrm{P}$ NMR (162 $\left.\mathrm{MHz}, \mathrm{CD}_{2} \mathrm{Cl}_{2}\right), \delta: 96.99 .{ }^{1} \mathrm{H} \mathrm{NMR}\left(401 \mathrm{MHz}, \mathrm{CD}_{2} \mathrm{Cl}_{2}\right), \delta$ : $7.59\left(\mathrm{~d}, 1 \mathrm{H},{ }^{3} J_{\mathrm{H}-\mathrm{H}}=2.3 \mathrm{~Hz}, \mathrm{CH}=\right), 7.47\left(\mathrm{~d}, 1 \mathrm{H},{ }^{3} J_{\mathrm{H}-\mathrm{H}}=2.1\right.$ $\mathrm{Hz}, \mathrm{CH}=), 7.34-7.27(\mathrm{~m}, 3 \mathrm{H}, \mathrm{CH}=), 7.09\left(\mathrm{t}, 1 \mathrm{H},{ }^{3} J_{\mathrm{H}-\mathrm{H}}=7.5\right.$ $\mathrm{Hz}, \mathrm{CH}=), 7.01\left(\mathrm{dd}, 1 \mathrm{H},{ }^{3} J_{\mathrm{H}-\mathrm{H}}=7.9,1.3 \mathrm{~Hz}, \mathrm{CH}=\right), 6.99-$ $6.88(\mathrm{~m}, 5 \mathrm{H}, \mathrm{CH}=), 5.84\left(\mathrm{~d}, 1 \mathrm{H},{ }^{3} J_{\mathrm{H}-\mathrm{H}}=8.1 \mathrm{~Hz}, \mathrm{CH}=\right), 4.57$ $\left(\mathrm{d}, 1 \mathrm{H},{ }^{2} J_{\mathrm{H}-\mathrm{H}}=14.6 \mathrm{~Hz}, \mathrm{CH}_{2}\right), 4.48\left(\mathrm{~d}, 1 \mathrm{H},{ }^{3} J_{\mathrm{H}-\mathrm{H}}=8.3 \mathrm{~Hz}\right.$, $\left.\mathrm{CH}_{2}-\mathrm{O}\right), 4.38$ (m, $\left.1 \mathrm{H}, \mathrm{CH}-\mathrm{N}\right), 4.29\left(\mathrm{~m}, 1 \mathrm{H}, \mathrm{CH}_{2}-\mathrm{O}\right), 3.71$ (d, $\left.1 \mathrm{H},{ }^{2} J_{\mathrm{H}-\mathrm{H}}=14.5 \mathrm{~Hz}, \mathrm{CH}_{2}\right), 2.52\left(\mathrm{~m}, 1 \mathrm{H}, \mathrm{CH},{ }^{i} \mathrm{Pr}\right), 1.60(\mathrm{~s}$, $\left.9 \mathrm{H}, \mathrm{CH}_{3},{ }^{t} \mathrm{Bu}\right), 1.54\left(\mathrm{~s}, 9 \mathrm{H}, \mathrm{CH}_{3},{ }^{t} \mathrm{Bu}\right), 1.34\left(\mathrm{~s}, 9 \mathrm{H}, \mathrm{CH}_{3},{ }^{t} \mathrm{Bu}\right)$, $1.30\left(\mathrm{~s}, 9 \mathrm{H}, \mathrm{CH}_{3},{ }^{t} \mathrm{Bu}\right), 1.07\left(\mathrm{~d}, 3 \mathrm{H},{ }^{\prime} \operatorname{Pr},{ }^{3} J_{\mathrm{H}-\mathrm{H}}=6.9 \mathrm{~Hz}\right), 1.03$ $\left(\mathrm{d}, 3 \mathrm{H},{ }^{i} \mathrm{Pr},{ }^{3} \mathrm{~J}_{\mathrm{H}-\mathrm{H}}=6.7 \mathrm{~Hz}\right) \cdot{ }^{13} \mathrm{C} \mathrm{NMR}\left(101 \mathrm{MHz}, \mathrm{CD}_{2} \mathrm{Cl}_{2}\right), \delta$ : $169.2(\mathrm{C}=\mathrm{N}), 151.7-121.3$ (aromatic carbons), $70.9(\mathrm{CH}-\mathrm{O})$, $69.8(\mathrm{CH}-\mathrm{N}), 34.5\left(\mathrm{CH}_{2}\right), 34.1(\mathrm{C}), 33.9(\mathrm{C}), 31.9\left(\mathrm{CH}_{3}\right.$, $\left.{ }^{t} \mathrm{Bu}\right), 31.6\left(\mathrm{CH}_{3},{ }^{t} \mathrm{Bu}\right), 31.4\left(\mathrm{CH}_{3},{ }^{t} \mathrm{Bu}\right), 31.0\left(\mathrm{CH}_{3},{ }^{t} \mathrm{Bu}\right), 30.0$ (C) $\left.{ }^{2} \mathrm{Pr}\right), 19.1\left(\mathrm{CH}_{3},{ }^{i} \mathrm{Pr}\right), 16.4\left(\mathrm{CH}_{3},{ }^{i} \mathrm{Pr}\right) .{ }^{19} \mathrm{~F}$ NMR $(377$ $\mathrm{MHz}, \mathrm{CD}_{2} \mathrm{Cl}_{2}$ ), $\delta:-78.01$. MS HR-ESI [found 840.3372, $\mathrm{C}_{47} \mathrm{H}_{61} \mathrm{NO}_{4} \mathrm{PPd}^{+}$requires 840.3368$]$.

\section{General procedure for Pd-catalyzed enantioselective Heck reactions with several triflates}

A mixture of $\left[\mathrm{Pd}_{2}(\mathrm{dba})_{3}\right] \cdot \mathrm{C}_{6} \mathrm{H}_{6}\left(12 \mathrm{mg}, 1.25 \times 10^{-2} \mathrm{mmol}\right)$ and the corresponding chiral ligand ( 2.3 equiv) in dry degassed solvent $(3.0 \mathrm{~mL})$ was stirred at room temperature for $20 \mathrm{~min}$. The corresponding olefin $(2.0 \mathrm{mmol})$, triflate $(0.50 \mathrm{mmol})$ and $N$-diisopropylethylamine $(1.0 \mathrm{mmol})$ were added to the catalyst solution. The vial was sealed and brought out and the solution was vigorously stirred at the desired temperature. After the desired reaction time, the reaction mixture was cooled to ambient temperature and internal standard (undecane, $0.5 \mathrm{mmol}$ ) was added. The mixture was diluted with additional diethyl ether and after agitation, the mixture was filtered through a short silica gel plug and analyzed by ${ }^{1} \mathrm{H}-\mathrm{NMR}$ or GC to determine the conversion and regioselectivity. The crude was subjected to flash chromatography (pentane/Et ${ }_{2} \mathrm{O}$ ) to give the purified product. Enantioselectivities were determined using chiral HPLC or GC (see Supporting Information for details).

\section{Pd-catalyzed enantioselective Heck reactions of 2,3- dihydrofuran with aryl halides}

$\left[\mathrm{Pd}(\mathrm{dba})_{2}\right] \cdot \mathrm{C}_{6} \mathrm{H}_{6}(8.5 \mathrm{mg}, 0.013 \mathrm{mmol})$ and ligand $(0.015$ $\mathrm{mmol})$ in degassed ethylene glycol $(1.0 \mathrm{~mL})$ were stirred at room temperature for $20 \mathrm{~min}$. Aryl halide $(0.50 \mathrm{mmol}), \mathrm{N}$ diisopropylethylamine $(255 \mu \mathrm{L}, 1.5 \mathrm{mmol}, 3$ equiv), silver triflate (192.7 mg, $0.75 \mathrm{mmol}, 1.5$ equiv) and 2,3dihydrofuran ( $75 \mu \mathrm{L}, 1.0 \mathrm{mmol}, 2$ equiv) were added to the catalyst solution. The vial was sealed and brought out and the mixture was vigorously stirred in an oil bath at $80 \mathrm{oC}$, for $24 \mathrm{~h}$. The reaction mixture was cooled to ambient temperature and internal standard (undecane, $0.5 \mathrm{mmol}$ ) was added. The mixture was diluted with additional diethyl ether and after agitation, the mixture was filtered through a short silica gel plug and analyzed by ${ }^{1} \mathrm{H}-\mathrm{NMR}$ or $\mathrm{GC}$ to determine the conversion and regioselectivity. The crude was subjected to flash chromatography (pentane/Et $2 \mathrm{O}$ ) to give the purified product. Enantioselectivities were determined using chiral HPLC or GC (see Supporting Information for details)

\section{Acknowledgements}

Financial support from the Spanish Ministry of Economy and Competitiveness (CTQ2016-74878-P, CTQ2015-69136-R, CTQ2016-81293-REDC/AEI) and European Regional Development Fund (AEI/FEDER, UE), the Catalan Government (2014SGR670, 2014SGR827 and 2017SGR1472), ICIQ (the Institute of Chemical Research of Catalonia) (Ph.D fellowship to Z. M.), the CNRS (GDRI Toulousse/Catalonia-HC3A) and the ICREA Foundation (ICREA Academia award to M.D), the Université Fédérale Toulouse Midi-Pyrénées (IDEX Chair to P.v.L.) is gratefully acknowledged. 


\section{References}

[1] For recent reviews, see: a) M. Oestreich, Angew. Chem. 2014, 126, 2314-2317; Angew. Chem. Int. Ed. 2014, 53, 2282-2285; b) M. Diéguez, O. Pàmies, in: Carbohydrates-tools for Stereoselective synthesis (Ed. M. M. K. Boysen), Wiley-VCH Verlag GmbH \& Co. KGaA, 2013, pp 245-251. c) D. Mc Cartney, P. J. Guiry, Chem. Soc. Rev. 2011, 40, 5122-5150; d) V. Coeffard, P. J. Guiry, Curr. Org. Chem. 2010, 14, 212-229; e) M. Oestreich, Mizoroki-Heck Reaction, Wiley-VCH, Weinheim, 2009; f) L. Y. Tietze, H. Ila, H. P. Bell, Chem Rev. 2004, 104, 3453-3516; g) L. X. Dai, T. Tu, S. L. You, W. P. Deng, X. L. Hou, Acc. Chem. Res. 2003, 36, 659-667; h) C. Bolm, J. P. Hildebrand, K. Muñiz, N. Hermanns, Angew. Chem., Int. Ed. 2001, 44, 32843308; i) M. Shibasaki, E. M. Vogl, in: Comprehensive Asymmetric Catalysis (Eds. E. N. Jacobsen, A. Pfaltz, H. Yamamoto), Springer, Heidelberg, 1999; j) O. Loiseleur, M. Hayashi, M. Keenan, N. Schemees, A. Pfaltz, J. Organomet. Chem. 1999, 576, 16-22; k) M. Beller, T. H. Riermeier, G. Stark, in: Transition Metals for Organic Synthesis (Eds. M. Beller, C. Bolm), WileyVCH, Weinheim, 1998; 1) F. Diederich, P. J. Stang, Metal-Catalyzed Cross-Coupling Reactions, WileyVCH, Weinheim, 1998; m) J. Magano, J. Dunetz, Chem. Rev. 2011, 111, 2177-2250; n) M. Diéguez, O. Pàmies, O. Isr. J. Chem. 2012, 52, 572-581.

[2] F. Ozawa, A. Kubo, T. Hayashi, J. Am. Chem. Soc. 1991, 113, 1417-1419.

[3] a) O. Loiseleur, P. Meier, A. Pfaltz, Angew. Chem. 1996, 108, 218-220; Angew. Chem. Int. Ed. Engl. 1996, 35, 200-202; b) O. Loiseleur, M. Hayashi, N. Schmees, A. Pfaltz, Synthesis 1997, 1338-1345.

[4] For representative examples, see: a) A. J. Hennessy, Y. M. Malone, P. J. Guiry, Tetrahedron Lett. 1999, 40, 9163-9165; b) A. J. Hennessy, D. J. Connolly, Y. Malone, M. P. J. Guiry, Tetrahedron Lett. 2000, 41, 7757-7761; c) Y. Hashimoto, Y. Horie, M. Hayashi, K. Saigo, Tetrahedron: Asymmetry 2000, 11, 2205-2211; d) M. Ogasawara, K. Yoshida, T. Hayashi, Heterocycles 2000, 52, 195-201; e) W.-P. Deng, X.-L. Hou, L.-X. Dai, X.-W. Dong, Chem. Commun. 2000, 1483-1484; f) S. R. Gilbertson, D. G. Genov, A. L. Rheingold, Org. Lett. 2000, 2, 2885-2888; g) S. R. Gilbertson, D. Xie, Z. Fu, J. Org. Chem. 2001, 66, 7240-7246; h) S. R. Gilbertson, Z. Fu, Org. Lett. 2001, 3, 161-164; i) T. Tu, W. P. Deng, X. L. Hou, L. X. Dai, Dong, X. C. Chem. Eur. J. 2003, 9, 3073-3081; j) T: Tu, X.-L. Hou, L. X. Dai, Org. Lett. 2003, 5, 3651-3653; k) T. G. Kilroy, G. P. Cozzi, N. End, P. J. Guiry, Synlett 2004, 106-110; 1) X. L. Hou, D. X. Dong, K. Yuan, Tetrahedron: Asymmetry 2004, 15, 2189-2193; m) T. G. Kilroy, P. G. Cozzi, N. End, P. J. Guiry, Synthesis 2004, 1879-1888; n) M. Rubina, W. M. Sherrill, M. Rubin, Organometallics 2008, 27, 6393-6395; o) W.-Q. Wu, Q. Peng, D.-X. Dong, X.-L. Hou, Y.-D. Wu, J. Am. Chem. Soc. 2008, 130, 9717-9725; p) D. Liu, Q. Dai, X. Zhang, Tetrahedron 2005, 61, 6460-6471; q) E. Bélanger, M.F. Pouliot, J.-F. Paquin, Org. Lett. 2009, 11, 2201-2204; r) M. O. Fitzpatrick, H. Müller-Bunz, P. J. Guiry, Eur. J.
Org. Chem. 2009, 1889-1895; s) É. Belanger, M.-F. Pouliot, M.-A. Courtemanche, J.-F. Paquin, J. Org. Chem. 2012, 77, 317-331; t) D. McCartney, Ch. Nottingham, H. Müller-Bunz, P. J. Guiry, J. Org. Chem. 2015, 80, 10151-10162; u) M. Rubina, W. M. Sherrill, A. Y. Barkov, M. Rubin. Beilstein J. Org. Chem. 2014, 10, 1536-1548.

[5] To a lesser extension phosphinite-oxazoline, phosphine$\mathrm{N}$ ( $\mathrm{N}=$ pyridine, amine, phenylbenzoxazine, thiazole, imidazole have also been applied. See for example: a) K. Yonehara, K. Mori, T. Hashizume, K. G. Chung, K. Ohe, S. Uemura, J. Organomet. Chem. 2000, 603, 4049; b) A. V. Malkov, M. Bella, I. G. Stará, P. Kocŏvsky, Tetrahedron Lett. 2001, 42, 3045-3048; c) G. H. Bernardinelli, E. P. Kündig, P. Meier, A. Pfaltz, K. Radkowski, N. Zimmermann, M. Neuburger-Zehnder, Helv. Chim. Acta 2001, 84, 3233-3246; d) T. G. Kilroy, A. J. Hennessy, D. J. Connolly, Y. M. Malone, A. Farrell, P. J. Guiry, J. Mol. Cat. A: Chem. 2003, 196, 65-81; e) W. J. Drury III, N. Zimmermann, M. Keenan, M. Hayashi, S. Kaiser, R. Goddard, A. Pfaltz, Angew. Chem. 2004, 116, 72-76; Angew. Chem. Int. Ed. 2004, 116, 70-74; f) P. Kaukoranta, K. Källström, P. G. Andersson, Adv. Synth. Catal. 2007, 349, 2595-2602; g) S. T. Henriksen, P. O. Norrby, P. Kaukoranta, P. G. Andersson, J. Am. Chem. Soc. 2008, 130, 10414-10421; h) E. W. Werner, T.-S. Mei, A. J. Burckle, M. S. Sigman, Science 2012, 338, 1455-1458; i) G. M. Borrajo-Calleja, V. Bizet, T. Bürgi, C. Mazet, Chem. Sci. 2015, 6, 48074811.

[6] P. Nilsson, H. Gold, M. Larhed, A. Hallberg, Synthesis 2002, 1611-1614.

[7] a) G. Helmchen, S. Kudis, P. Sennhenn, H. Steinhagen, Pure Appl. Chem. 1997, 69, 513-518; b) A. Pfaltz, Acta Chem. Scand. 1996, 50, 189-194; c) J. M. J. Williams, Synlett 1996, 705-710; d) G. Helmchen, A. Pfaltz, Acc. Chem. Res. 2000, 33, 336-345.

[8] a) T. H. Wöste, M. Oestrich, Chem. Eur. J. 2011, 17, 11914-11918; b) J. Liu, J. Zhou, Chem. Commun. 2013, 49, 11758-11760; c) J. Hu, Y. Hu, Y. Li, J. Zhou, Chem. Commun. 2013, 49, 9425-9427; d) C. Wu, J. Zhou, J. Am. Chem. Soc. 2014, 136, 650-652; e) Recently Hou's and Ding's groups reported the use of phosphinephosphine oxides for the construction of quaternari carbon centers, see. Q.-S. Zhang, S.-L. Wan, D. Chen, C.-H. Ding, X.-L. Hou, Chem. Comm. 2015, 51, 1223512238.

[9] P. W. N. M. van Leeuwen, P. C. J. Kamer, C. Claver, O. Pàmies, M. Diéguez, Chem. Rev. 2011, 111, 2077-2118.

[10] a) M. Diéguez, O. Pàmies, Acc. Chem. Res. 2010, 43, 312-322; b) O. Pàmies, P. G. Andersson, M. Diéguez, Chem. Eur. J. 2010, 16, 14232-14240; c) M. Magre, O. Pàmies, M. Diéguez, Chem. Rec. 2016, 16, 1578-1590; d) O. Pàmies, M. Diéguez, Chem. Rec. 2016, 16, 24602481.

[11] a) Y. Mata, M. Diéguez, O. Pàmies, C. Claver, Org. Lett. 2005, 7, 5597-5599; b) Y. Mata, O. Pàmies, M. Diéguez, Chem. Eur. J. 2007, 13, 3296-3304; c) J. 
Mazuela, O. Pàmies, M. Diéguez, Chem. Eur. J. 2010, 16, 3434-3440.

[12] See for example ref 11c where we demonstrated that the replacement of the phosphine moiety by a biaryl phosphite group led to a substantial increase of the catalytic activity. Thus, for instance, while the phenylation of S1 using Pd/phosphine-oxazoline PHOX requires 4 days to achieve full conversion, only $24 \mathrm{~h}$ are needed when using related phosphite-oxazoline PHOXtype ligands. For other examples, see: a) J. Mazuela, P. Tolstoy, O. Pàmies, P. G. Andersson, M. Diéguez, Org. Biomol. Chem. 2011, 9, 941-946; b) ref. 11 b.

[13] See for instance: a) G. F. P. van Strijdonck, M. D. K. Boele, P. C. J. Kamer, J. G. de Vries, P. W. N. M. van Leeuwen, Eur. J. Inorg. Chem. 1999, 1073-1076; b) T. Rosner, J. Le Bars, A. Pfaltz, D. G. Blackmond, J. Am. Chem. Soc. 2001, 123, 1848-1855; c) T. Rosner, A. Pfaltz, D. G. Blackmond, J. Am. Chem. Soc. 2001, 123, 4621-4622; d) G. Rothenberg, S. C. Cruz, G. P. F. van Strijdonck, H. C. J. Hoefsloot, Adv. Synth. Catal. 2004, 346, 467-473. e) D. L. Dodds, M. D. K. Boele, G. P. F. van Strijdonck, J. G. de Vries, P. W. N. M. van Leeuwen, P. C. J. Kamer, Eur. J. Inorg. Chem. 2012, 1660-1671; f) J. S. Mathew, M. Klussmann, H. Iwamura, F. Valera, A. Futran, E. A. C. Emanuelsson, D. G. Blackmond $J$. Org. Chem. 2006, 71, 4711-4722.

[14] K. K. Hii, T. D. W. Claridge, J. M. Brown, J. M. Angew. Chem. 1997, 109, 1033-1036; Angew. Chem. Int. Ed. 1997, 36, 984-987.

[15] Ligands L1-L3a-e have been previously successfully used in asymmetric hydrogenation of $\beta$-cyclic enamides and minimally functionalized olefins, see: a) M. Magre, O. Pàmies, M. Diéguez, ACS Catal. 2016, 6, 5186-5190; b) M. Biosca, M. Magre, M. Coll, O. Pàmies, M. Diéguez, Adv. Synth. Catal. 2017, 359, 2801-2814.

[16] D. Yang, L. Wang, F. Han, D. Li, D. Zhao, R. Wang, Angew. Chem. 2015, 127, 2213-2217; Angew. Chem. Int. Ed. 2015, 54, 2185-2189.

[17] D. C. Harrowven, M. C. Lucasa, P. D. Howes, Tetrahedron 2001, 57, 791-804.

[18] The use of commercially available $\left[\mathrm{Pd}_{2}(\mathrm{dba})_{3}\right] \cdot \mathrm{dba}$ led to some reproducibility problems between batches due to the presence of different amounts of free dba. For these reason we removed the free $\mathrm{dba}$ by recrystallization in benzene. S. S. Zalesskiy, V. A. Ananikov, Organometallics 2012, 31, 2302-2309.

[19] S. Takano, K. Dsmizu, K. Ogasawara, Synlett 1993, 393-394.

[20] To our knowledge only three reports deals with the coupling of substrate S2. a) Pfaltz et al., in ref $3 b$, reported the phenylation of $\mathbf{S} 2$ with $\mathrm{Pd} / \mathbf{3}$ system with $92 \%$ ee and $70 \%$ conv in 7 days using higher temperature $\left(70{ }^{\circ} \mathrm{C}\right)$; b) Gilberston et al., in ref. $4 \mathrm{~g}$, reported the phenylation of $\mathbf{S} 2$ with $\mathrm{Pd} / \mathbf{4}$ system with $96 \%$ ee and $50 \%$ conversion in 2 days using higher temperature $\left(70{ }^{\circ} \mathrm{C}\right)$; c) Zhou et al., in ref $8 \mathrm{~b}$, reported the coupling of $\mathbf{S 2}$ with 1-Napf-OTf using $(R)-\mathrm{Xyl}$ -
SDP(O)biphosphine oxide ligand with $92 \%$ ee in 2 days at $50{ }^{\circ} \mathrm{C}$.

[21] For representative examples, see: a) D. Antonow, D. E. Thurston, Chem. Rev. 2011, 111, 2815-2864; b) A. B. Smith III, A. K. Charnley, R. Hirschmann, Acc. Chem. Res. 2011, 44, 180-193; c) K. M. Rahman, C. H. James, T. T. T. Bui, A. F. Drake, D. E. Thurston, J. Am. Chem. Soc. 2011, 133, 19376-19385; d) D. Antonow, M. Kaliszczak, G. D. Kang, M. Coffils, A. C. Tiberghien, N. Cooper, T. Barata, S. Heidelberger, C. H. James, M. Zloh, T. C. Jenkins, A. P. Reszka, S. Neidle, S. M. Guichard, D. I. Jodrell, J. A. Hartley, P. W. Howard, D. E. Thurston, J. Med. Chem. 2010, 53, 2927-2941; e) J. Lloyd, H. J. Finlay, W. Vacarro, T. Hyunh, A. Kover, R. Bhandaru, L. Yan, K. Atwal, M. L. Conder, T. JenkinsWest, H. Shi, C. Huang, D. Li, H. Sun, P. Levesque, Bioorg. Med. Chem. Lett. 2010, 20, 1436-1439; f) K. M. Rahman, H. Vassoler, C. H. James, D. E. Thurston, $A C S$ Med. Chem. Lett. 2010, 1, 427-432.

[22] C. C. Oliveira, A. Pfaltz, C. R. D. Correia, Angew. Chem. 2015, 127, 14242-14245; Angew. Chem. Int. Ed. 2015, 54, 14036-14039.

[23] T.-S. Mei, E. W. Werner, A. J. Burckle, M. S. Sigman, J. Am. Chem. Soc. 2013, 135, 6830-6833.

[24] Z. Yang, J. Zhou, J. Am. Chem. Soc. 2012, 134, 1183311835.

[25] J. F. Hartwig, Organotransition Metal Chemistry, University Science Books, Sausalito, 2010, pp 893-895.

[26] M. Tschoerner, P. S. Pregosin, A. Albinati, Organometallics 1999, 18, 670-678.

[27] G. J. H. Buisman, L. A. van der Veen, A. Klootwijk, W. G. J. de Lange, P. C. J. Kamer, P. W. N. M. van Leeuwen, D. Vogt, Organometallics 1997, 16, 29292939.

[28] Attempted microcalorimetry measurements were frustrated by the ingress of water in the system.

[29] The kinetic results are surprisingly simple within the boundaries studied, which was not expected in view of the apparent importance of solvents and the anions presents. The weak coordination of triflates explains probably the simple kinetics we encountered.

[30] C. Hansch, A. Leo, R. W. Taft, Chem. Rev. 1991, 91, 165-195.

[31] J. F. Hartwig, Organotransition Metal Chemistry. From Bonding to Catalysis; University Science Books, Sausalito, 2010.

[32] As found in model work for polyketone catalysis itself, migration is orders of magnitude slower for asymmetric $\mathrm{P}-\mathrm{N}$ ligands than for both symmetric $\mathrm{P}-\mathrm{P}$ and $\mathrm{N}-\mathrm{N}$ ligands. Slow migratory insertions in systems based on $\mathrm{P}-\mathrm{N}$ ligands derive from the difference in the trans influences of the two donors, which for phosphiteoxazolines is smaller than the difference in phosphineoxazoline complexes. See: a) G. P. C. M. Dekker, C. J. Elsevier, K. Vrieze, P. W. N. M. van Leeuwen, C. F. Roobeek, J. Organomet. Chem. 1992, 430, 357-372; b) 
G. P. C. M. Dekker, A. Buijs, C. J. Elsevier, K. Vrieze, P. W. N. M. van Leeuwen, W. J. J. Smeets, A. L. Spek, Y. F. Wang, C. H. Stam, Organometallics 1992, 11, 1937-1948.

[33] P. W. N. M. van Leeuwen, C. F. Roobeek, H. van der Heijden, J. Am. Chem. Soc. 1994, 116, 12117-12118.
[34] G. J. H. Buisman, P. C. J. Kamer, P. W. N. M. van Leeuwen, Tetrahedron: Asymmetry 1993, 4, 1625-1634.

[35] J. C. Holder, L. Zou, A. N. Marziale, P. Liu, Y. Lan, M. Gatti, K. Kikushima, K. N. Houk, B. M. Stoltz, J. Am. Chem. Soc. 2013, 135, 14996-15007. 


\section{FULL PAPER}

Synthesis, Application and Kinetic studies of Chiral Phosphite-Oxazoline Palladium Complexes as Highly Active and Selective Catalysts in Intermolecular Heck Reactions

Adv. Synth. Catal. Year, Volume, Page - Page

Zahra Mazloomi, Marc Magre, Efrem Del Valle, Miquel A. Pericàs, Oscar Pàmies, ${ }^{*}$ Piet. W. N. M.
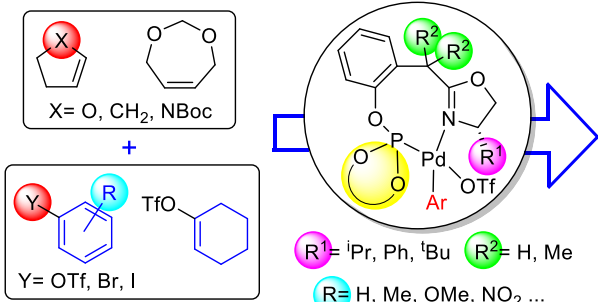

$R^{1}=\mathrm{i} P r, \mathrm{Ph},{ }^{\mathrm{B} u} \mathrm{R}^{2}=\mathrm{H}, \mathrm{Me}$ $\mathrm{R}=\mathrm{H}, \mathrm{Me}, \mathrm{OMe}, \mathrm{NO}_{2} \ldots$

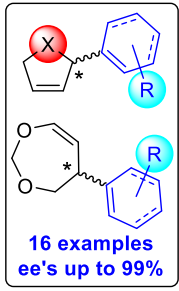

van Leeuwen* and Montserrat Diéguez* 